\title{
EL PERÚ Y LAS PARADOJAS DE CALIMERO
}

\section{PERU AND THE PARADOXES OF CALIMERO}

Carlos Gamero Esparza: Universidad Inca Garcilaso de la Vega (Perú)

carlos.gamero@ozu.es

\section{CURRÍCULUM VITAE}

Reconocido Periodista peruano del Diario OJO de Lima. Licenciado con Diploma de Honor en la Universidad Inca Garcilaso de la Vega.

\section{RESUMEN}

El pasado 20 de enero se celebró el aniversario de la derrota peruana en la batalla de Yungay que marcó el fin de la Confederación Perú-boliviana, y el 3 de octubre fue el $40^{\circ}$ aniversario del golpe de estado del general Juan Velasco Alvarado, que derrocó al presidente Belaunde para instaurar la Revolución Peruana, una dictadura militar. El Perú de hoy no es solo la consecuencia de la acción de quienes lideraron los acontecimientos políticos y sociales de turno durante el agitado periodo Republicano. La historia republicana del Perú durante del resto del siglo XIX y los comienzos del XX fue un cúmulo de desaciertos y contradicciones, matizados por las injusticias, la violencia interna, los golpes de estado, el caudillismo, la veleidad de los líderes políticos y militares, las deportaciones, las pérdidas casi crónicas de territorios enteros -por medio de cesiones por parte de gobernantes irresponsables o 
a causa de conflictos armados, etc., que a la larga mermaron la soberanía nacional-, creó un caldo de cultivo para la insatisfacción, el descontento y el conflicto social.

\title{
PALABRAS CLAVE
}

Perú - Confederación - Revolución - Dictadura militar

\begin{abstract}
On January 20 is celebrated the anniversary of Peru's defeat at the Battle of Yungay, which marked the end of the Peru-Bolivian Confederation, and on 3 October was the 40th anniversary of the coup of General Juan Velasco Alvarado, overthrew President Belaunde to establish the Peruvian Revolution, a military dictatorship. Peru today is not only the result of the action of those who led the political and social events of the day during the hectic period Republican. The history of the Republic of Peru during the rest of the nineteenth and early twentieth centuries was an accumulation of mistakes and contradictions, colored by the injustices, the internal violence, coups, warlordism, the fickleness of political leaders and military deportations, almost chronic loss of the entire territory, by sales by irresponsible rulers or because of armed conflicts, etc.., that ultimately diminished the national sovereignty, created a breeding ground for dissatisfaction, discontent and social conflict.
\end{abstract}

\section{KEY WORDS}

Peru - Confederation - Revolution - Military dictatorship 


\section{ÍNDICE}

Una introducción para un tema existencial

1. Los miedos existenciales del Perú

1.1. Tres sátiras de la misma cuestión

1.2. La parodia de los ídolos de barro

2. Palabra de escribidor

3. El trauma de la Historia del Perú

3.1. Al grano... ¿qué quiere decir Jodió?

4. El Perú que nos dejó la cruel paradoja de Yungay... y una dictadura militar

4.1. ¿En qué momento se jodió el Perú?

5. Maldición mapuche, ¿realismo o paranoia?

6. Para saber más...

7. Epílogo: un poco de optimismo no hace daño (hay quienes piensan diferente...)

7.1. Los andinos tenemos una mirada abarcadora

8. Notas al Margen y Referencias

9. Origen de las ilustraciones

10. Recortes de Prensa

10.1. Después de que se jodió el Perú

10.2. Texto completo del reportaje de Francisco Igartua: ¿En qué momento se jodió el Perú?, publicado en la revista Oiga del 5 de setiembre de 1995

10.3. La Revolución Peruana

10.4. El 'Limazo'

10.4.1. La Separata 


\section{TEXTO}

Desde la puerta de La Crónica Santiago mira la avenida Tacna, sin amor: automóviles, edificios desiguales y descoloridos, esqueletos de avisos luminosos flotando en la neblina, el mediodía gris. ¿En qué momento se había jodido el Perú? Los canillitas merodean entre los vehículos detenidos por el semáforo de Wilson voceando los diarios de la tarde y él echa a andar, despacio, hacia la Colmena. Las manos en los bolsillos, cabizbajo, va escoltado por transeúntes que avanzan, también, hacia la Plaza San Martín. El era como el Perú, Zavalita, se había jodido en algún momento. Piensa: ¿en cuál? Frente al Hotel Crillón un perro viene a lamerle los pies: no vayas a estar rabioso, fuera de aquí. El Perú jodido, piensa, Carlitos jodido, todos jodidos. Piensa: no hay solución. Ve una larga cola en el paradero de los colectivos a Miraflores, cruza la Plaza y ahí está Norwin, hola hermano, en una mesa del Bar Zela, siéntate Zavalita, manoseando un chilcano y haciéndose lustrar los zapatos, le invitaba trago. No parece borracho todavía y Santiago se sienta, indica al lustrabotas que también le lustre los zapatos a él. Listo jefe, ahoritita jefe, se los dejaría como espejos, jefe. De: Conversación en la Catedral. Mario Vargas Llosa. (Nota 1)

Una introducción para un tema existencial

El 20 de enero último y el 3 de octubre del año pasado se cumplieron dos efemérides que pasaron prácticamente desapercibidos, pero que en su álgido momento marcaron gravemente la Historia del Perú. La primera fecha nos remite a la derrota peruana en la batalla de Yungay (20/1/1839), por parte del Ejército Unido Restaurador, procedente de Chile, lo que marcó el fin de la Confederación Perúboliviana, y la segunda, el $40^{\circ}$ aniversario del golpe de estado del general Juan Velasco Alvarado (3/10/1968), quien derrocó al entonces presidente Fernando Belaunde Terry para instaurar una insólita "Revolución Peruana", una dictadura militar que sin duda será recordada por siempre como uno de los peores gobiernos 
de nuestra historia contemporánea. Ambas fechas, aparentemente inconexas, han sido objeto de una ardua discusión sobre el dilema existencial del Perú y los peruanos, desde que el escritor Mario Vargas Llosa publicó su exitosa novela Conversación en la Catedral (1969), donde colocó en boca de uno sus personajes, de nombre Zavalita, la frase: ¿En qué momento se jodió el Perú? Dicha oración parece resumir de manera genial las inquietudes más escondidas de todo un pueblo y expresa su desconcierto por un presente que no puede deshacerse de su añoso pasado. Las peores pesadillas, los peores temores, las dudas sobre la historia que se enseña en los colegios, y la eterna incertidumbre acerca de la realidad peruana resumen una crisis existencial que ya dura casi dos centurias, parece marcar la vida cotidiana de un país que parece haber crecido incompleto. La polémica ha dividido a los intelectuales peruanos y aún a los extranjeros, pues, mientras para unos es verdad que existe una crisis existencial en la sociedad peruana que parece haberse agudizado desde la segunda mitad del siglo XX, resumida en la celebérrima expresión de Zavalita; para otros, esto no sería más que imaginación popular, un mito social, una leyenda urbana. Pero la gran verdad es que nadie puede rehuir a ese "no sé qué" que flota vaporoso entre las brumas invernales limeñas, nadie puede eludir ese sentimiento amargo, la desazón que provoca recordar hechos históricos dolorosos y frustrantes. ¿Es el Perú actual la suma de sus yerros históricos y absurdas realidades... o acaso todo ha sido una sarta de crueles ironías históricas o, en su defecto, producto de una aleve "mala suerte", que sino una "maldición" como algunos afirman?

El Perú de hoy es un descolorido enredo de infortunios, desmemorias y fracasos crónicos. Eso es lo que se puede notar claramente cuando revisamos un libro sobre su historia. Allí, los episodios de la Conquista y la República decimonónica pueden dejarlo a uno con el sinsabor del pesimismo. En esas páginas llenas de esperanzas rotas y penosos desenlaces, se puede percibir ese tufillo de desesperanza y frustración, todo reflejado en tanto equivoco político, en tanta derrota bélica, en tanta 
pérdida de territorios, en tanta contradicción social, en tanta falta de amor propio de parte de los actores de la historia, en tanta inmoralidad y corrupción incluso en las más altas esferas del poder, en tanto pillaje entre paisanos, en tanto desastre económico después de bonanzas y riquezas, en tanta debacle que marchitó el orgullo patrio y devastó moral y espiritualmente el "ego" nacional. Es como si estuviéramos asistiendo a la crónica de la "mala leche". Esto nos recuerda las historias del personaje que ha inspirado el título de este trabajo: Calimero, un pequeño pollito negro con la mitad de una cáscara de huevo sobre su cabeza y que solía repetir: Esto es una injusticia, expresión que se hizo tan famosa, especialmente en España y en otros países de habla castiza. Se trataba de unos encantadores dibujos animados que de alguna forma radiografiaban las viscitudes de la vida cotidiana de un hijo de vecino que sueña y que lucha por salir adelante; pero por desgracia, el pollito Calimero no contaba con "el destino" que finalmente le ponía la zancadilla sin mediar explicación alguna. Este comic, por extraño que parezca, ha resultado ser la descripción perfecta del drama peruano. Con sus historias plagadas de crueles ironías y un humor negro ácido y a veces sarcástico, Calimero vive en un mundo utópico donde todo empieza bien para terminar siempre mal. Y así como ocurría con el pollito de la mala suerte, la ambigüedad y el desconcierto de sus historias retratan al Perú de los últimos dos siglos pasados (XIX y XX). Muchos intelectuales pensantes parecen inferir todavía que este Perú que conocemos ahora, a pesar de sus bonanzas económicas, es un país que aún no congenia con los miedos internos del sentir de sus ciudadanos; tampoco parece haberse tomado conciencia de que este Perú no es solo la fascinante escenografía de un pasado milenario y glorioso, también ha habido ayeres incomprendidos que nos han marcado para siempre. En nuestro insólito y desconcertante presente, se percibe un conformismo indolente con la vieja idea que suele inculcarse desde las aulas escolares de que la historia está oleada y sacramentada y que nadie puede ponerla en tela de juicio. Es un pasado que ha quedado reducido al formato conveniente de los académicos e intereses de turno. Nadie dice que el Perú de ahora no ha sabido asumir las enseñanzas de ese ayer, 
razón por la cual parecemos condenados a repetir cuanto yerro y metida de pata se cometió desde las más altas esferas del poder hasta el hijo del vecino de la esquina. La gran verdad, por más que duela, es que en lugar de valorar las lecciones de nuestros antepasados, ha habido quienes se han empeñado en desacreditar a todo aquel que se haya atrevido a ir al fondo y agitar el lecho sobre el que descansa, muy seguro de sí mismo, un sistema establecido que persiste en sumir al hombre de la calle en la total oscuridad. Pese a las mediocridades de una intelectualidad "blanca" que siempre se sintió dueña de la verdad, nuestra verdadera historia, no la que nos han hecho creer, es un claro ejemplo de que el devenir de los hechos descritos no se rige para nada en los dogmas impuestos por el acartonamiento que omite la existencia de lo andino como elemento clave dentro del contexto nacional peruano. Gracias a la gran fuerza espiritual del pueblo andino, el Perú ha sido y es, por sobre todo, un país de todas las sangres y de todas las historias y de todas las contradicciones, y eso es lo que cuesta entender, aunque, afortunadamente, ya muchos se están dando cuenta de ello, para desazón de quienes siempre quieren tener la última palabra. Y eso es lo que no se quiere asumir por no aceptar nuestras raíces andinas. Por ello, uno de los peores errores de muchos intelectuales y "expertos" en materias sociológicas, históricas e incluso antropológicas, ha sido, justamente, la sistemática y casi patológica tendencia a negar a toda costa esta realidad. Se trata de una absurda negación de lo "indígena", de lo "andino", como patrón desarrollador de la nacionalidad peruana. Es como el caso de Chile y Argentina, donde se margina y discrimina a la etnia mapuche, otrora amos y señores de esta región sudamericana. La historia ha dado suficientes ejemplos de cómo esta actitud tan "docta", de este comportamiento tan "castrante" y poco razonable de negar las realizaciones de gentes que no sean las "blancas" o similares, ha traído por consiguiente desastrosas consecuencias, tales como las que vamos a reseñar en este trabajo. Algunos historiadores peruanos, tan poco indulgentes con variar el anquilosado "esquema establecido" en el estudio de nuestro ayer, se han desentendido mucho con la idea de que los verdaderos protagonistas de esa 
"Historia del Perú" que se enseña en las aulas han sido esos mal llamados "indios primitivos" que crearon la civilización andina. Una civilización cuyos herederos todavía son sistemáticamente segregados por ese centralismo mental -por no decir "limeño" - que pretende ignorar que en el Perú si uno no tiene algo de inga, pues tiene de mandinga, que sino ambos, pero jamás ninguno. Esa es la gran certeza. Entender al verdadero Perú, no al país de la careta marketera y el maquillaje turístico en desmedro de los propios peruanos, es entender a ese país profundo de las honduras andinas, de la lujuriante amazonia, de los ubérrimos valles costeros; entender al verdadero Perú implica olvidarse del patrón "blanco" de una sociedad que no mira sus espaldas; implica, además, admitir que se trata de un universo social complejo, multirracial y multicultural y, a la vez, tan unido a la tierra que lo vio nacer; implica asimismo reconocer su existencialidad andina como un todo, que representa a culturas y tradiciones antiquísimas cuyos rasgos no se pueden obviar.

El presente trabajo pretende analizar la ardua discusión generada por algunos acontecimientos de aquel pasado aquí citados, cuyas secuelas ahora no dejan de causar cierta zozobra y cuestionamientos sobre el ser y no ser de los peruanos. Se trata de algo que, por más que uno se quede callado, no puede soslayarse de la extraña sensación de que el Perú de hoy no es el Perú que debió haber sido, que algo de nuestro pasado tiene que ser resuelto, que algo en nuestra psique sigue latente e inconforme con las explicaciones académicas de nuestros "geniales" intelectuales, incapaces de profundizar en aquello que se resume en una pregunta acuciante: ¿En qué momento se jodió el Perú?

\section{Los miedos existenciales del Perú}

El Perú de hoy no es solo la consecuencia de la acción de quienes lideraron los acontecimientos políticos y sociales de turno durante el agitado periodo Republicano que tanto describen los libros; menos ha sido producto de una aristocracia -muchas 
veces oportunista - ni mucho menos la hegemonía de quienes detentaron el mando político y la influencia social y económica en su tiempo. Está demás decir que aunque algunos atribuyen esto a una sobreexposición de minorías ricas sobre mayorías pobres o marginales, la verdad es que esto es solo una arista de ese enorme laberinto llamado Perú. El viejo país de los incas de hoy es un crisol multirracial y multicultural que con el tiempo generó una nacionalidad postergada e incompleta. Es una nacionalidad que no ha podido ser asimilada del todo por el subconsciente colectivo a causa de sus contradicciones históricas y hechos incomprensibles que pocos han podido explicar en su real dimensión. Se trata, dicho de otra forma, de una identidad nacional malbaratada desde que este país decidió ser país, e incluso desde mucho antes; malbaratada por los desaciertos, la mediocridad y la irresponsabilidad de nuestras clases dirigentes; malbaratada por la desilusión y la decepción del pueblo peruano a través de los años debido a los constantes fracasos históricos, que en nada han contribuido en alimentar el orgullo nacional. Para algunos historiadores, lo que vivimos ahora es una "herencia" del primer tercio del siglo XIX, cuando, en medio de un torbellino de sentimientos encontrados, conflictos armados y rebeliones internas, surgió una clase política amorfa, sin ideas, sin identidad propia, que respondía más bien al interés personal antes que al bienestar de la comunidad; para esta minoría que medraba a expensas de una gran mayoría, las aspiraciones e inquietudes colectivas eran lo de menos; se trataba de una clase política que haría reflejar en el pueblo la suma de sus taras y complejos. Y con esta, imperó una sociedad sin valores morales ni identidad propia, que se dejaba llevar por apasionamientos triviales, mezquinos y falaces. Con esto, la historia republicana del Perú durante del resto del siglo XIX y los comienzos del XX fue un cúmulo de desaciertos y contradicciones, matizados por las injusticias, la violencia interna, los golpes de estado, el caudillismo, la veleidad de los líderes políticos y militares, las deportaciones, las pérdidas casi crónicas de territorios enteros -por medio de cesiones por parte de gobernantes irresponsables o a causa de conflictos armados, etc., que a la larga mermaron la soberanía nacional - , creó un caldo de cultivo para la insatisfacción, el descontento y 
el conflicto social. Lo malo de todo esto es que nuestras sociedades contemporáneas son quienes están pagando ahora el pato y son el claro reflejo de lo que nos dejaron nuestros antepasados. Contra natura de las leyes históricas esgrimidas por algunos autores tan notables como Arnold Toymbee, en el Perú se desarrolló lo que algunos han bautizado como la cultura de la derrota (Nota 2), es decir, un sentimiento de resignada mediocridad e inferioridad, el peruano no solo ha perdido la capacidad de indignación, sino que además da muestras de un derrotismo casi esquizofrénico, una resignación incapacitante, reflejo de una inacción desidiosa en todo sentido, que impide mayores realizaciones y logros personales o colectivos en todo sentido, como ha sucedido, lastimosamente, con el fútbol peruano, otrora reconocido como potencia en Sudamérica (Nota 3). Por eso se dice que en el Perú la gente le tiene miedo al éxito o, en su defecto, se dice que aquí el fracaso parece ser más atractivo que la victoria. La corrupción política y moral en grado superlativo -enfermedad también heredada de nuestros antepasados cercanos del siglo XIX y primeras décadas del XX-, la carencia de valores éticos, el racismo -el de hoy, lamentablemente, no es diferente al de ayer-, amén de la marginación y la discriminación entre peruanos, son solo algunas puntas del inmenso iceberg que es esta tragicomedia llamada Perú.

\subsection{Tres sátiras de la misma cuestión...}

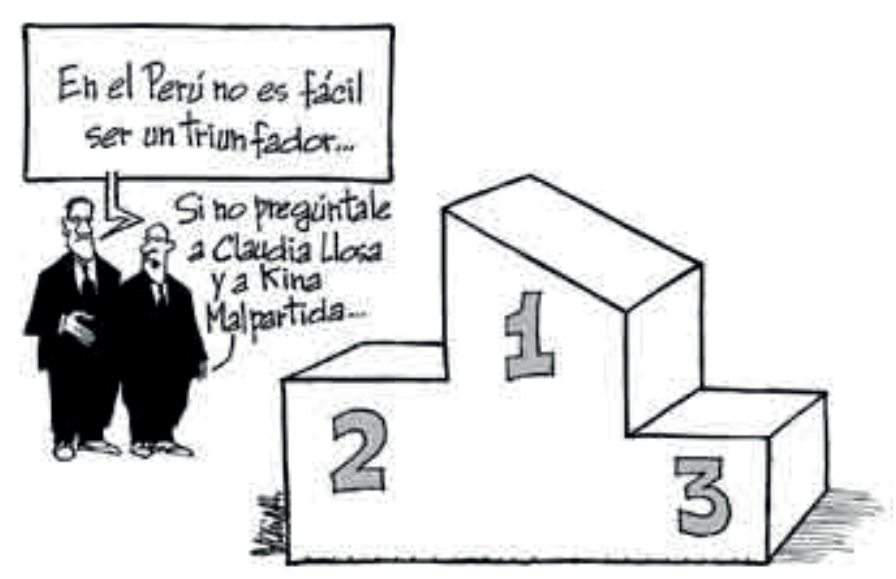


Figura 1a. Curiosa caricatura publicada recientemente en el diario El Comercio de Lima, que retrata una actitud muy peruana, ironizando la polémica creada por la negativa oficial de reconocer los éxitos de dos mujeres: una cineasta ganadora de un premio internacional (Claudia Llosa) y una boxeadora campeona mundial (Kina Malpartida). A la primera no la querían tomar en cuenta porque su película ganadora en el Festival de Berlín, La teta asustada, "era fea"; y a la segunda... no le querían dar los laureles deportivos por dudar de su nacionalidad y considerarla "australiana". Las autoridades tuvieron que dar marcha atrás. Ilustración de Molina, en Humor Profano.

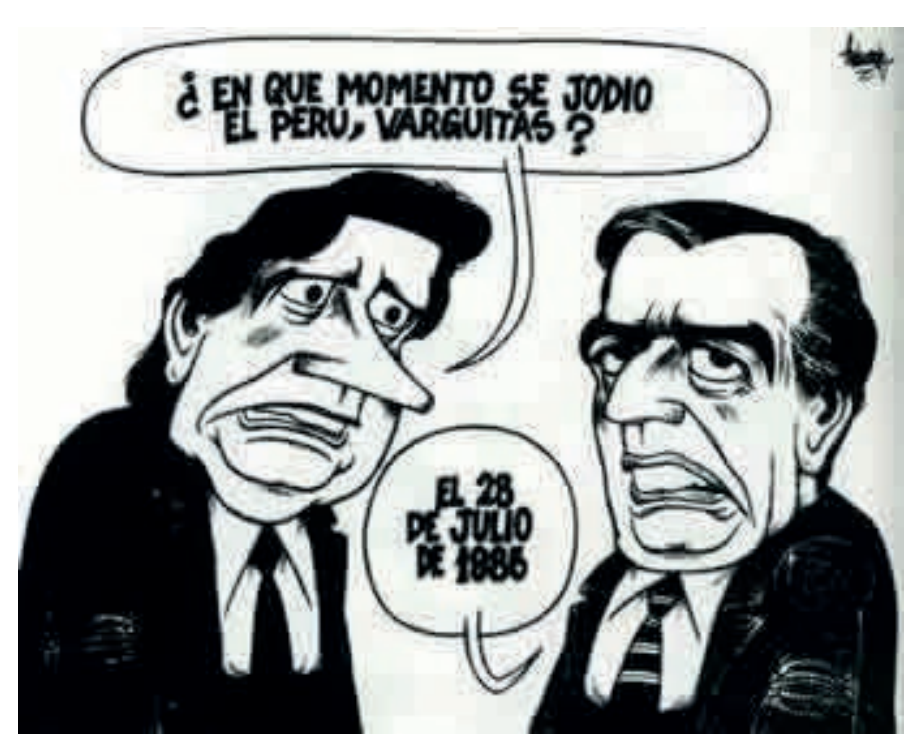

Figura 1b. Dibujo de 1988, publicado en la revista Caretas, obra del genial caricaturista Eduardo Rodríguez (Heduardo). Aquí vemos a Alan García, que asumió la Presidencia de la República el 28 de julio de 1985, en un diálogo con Mario Vargas Llosa, quién, claro está, se refiere al desastroso e hiper-inflacionario primer gobierno del líder aprista, al decir que el Perú se jodió en esa fecha... Ilustración publicada en el sitio Mario Vargas Llosa en caricatura. 


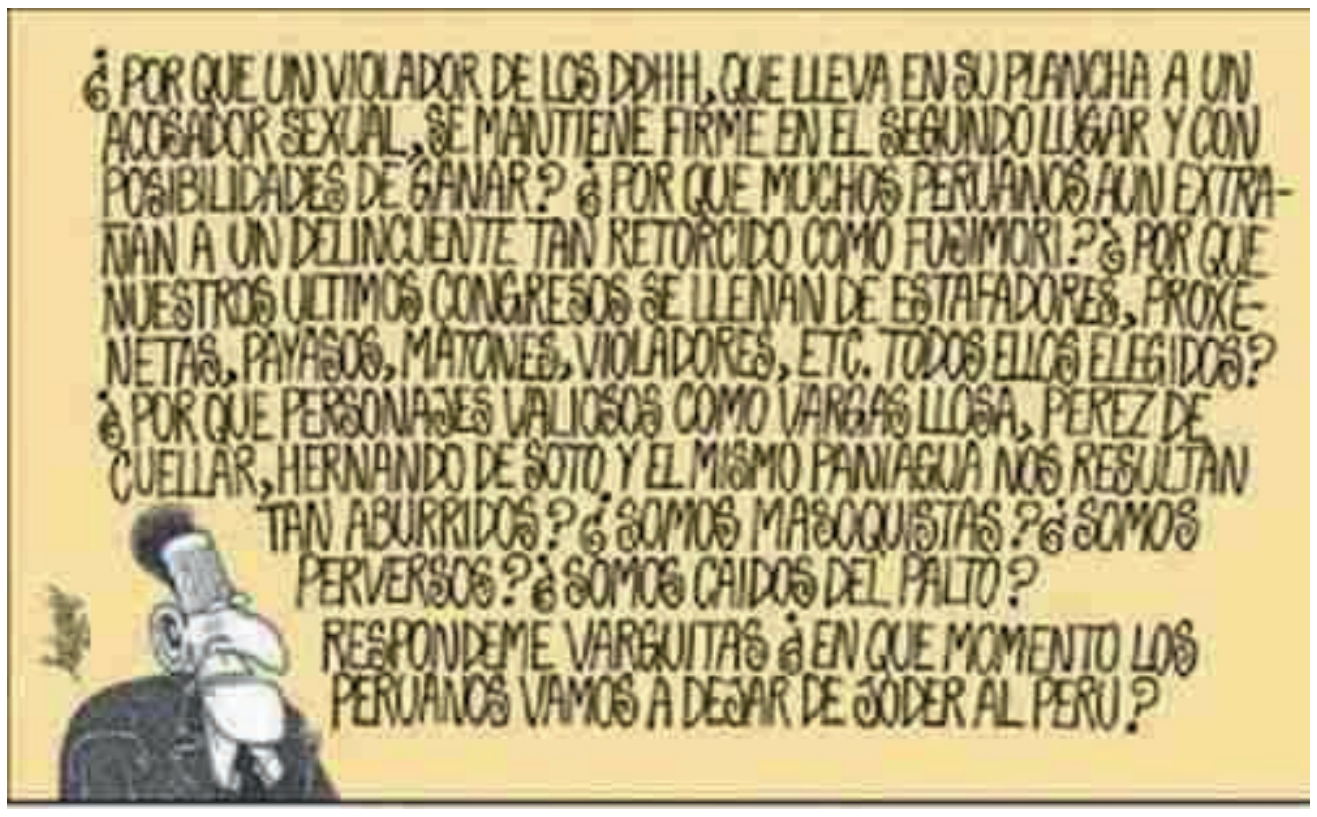

Figura 1c. Otra genial ilustración del dibujante Heduardo, publicada en el diario Perú 21. La leyenda debajo de este dibujo dice lo siguiente... Esta caricatura resume todo el cuestionamiento que nos hacemos muchos. Es que somos los culpables inconscientes de todo cuanto pase. Despertamos y le echamos la culpa siempre al otro. El pueblo tiene al gobernador que se merece. Nosotros somos los que decidimos. Hay mucha ignorancia. Y la ignorancia hace a las personas más manejables. A los políticos les interesa manejarnos. El problema de fondo es la educación. Acabar con la pereza mental, el ocio. Aparte, la verdadera lucha es interna. No está en el presidente o los congresistas el verdadero cambio, si nosotros no cambiamos de mentalidad. Nosotros somos los que decidimos.

Si decidimos mal, sin reflexionar, sin pensar bien en la consecuencia de nuestros actos, seguiremos jodiendo al Perú. Todo depende de nosotros. Texto en cursiva del blog Escrito en el Agua. ¿En qué momento se jodió el Perú? Lima, 16 de febrero de 2006. 


\subsection{La parodia de los ídolos de barro}

Como si de una condena infame se tratara, la historia del Perú parece ser el relato inmutable de nuestros fracasos, de nuestros yerros, de nuestras penas y resignaciones ante lo irremediable. Es la historia de actos heroicos convertidos en triunfos morales, victorias que de poco o nada sirvieron, o derrotas "honrosas" que reflejaron un bajísimo nivel de autoestima en el peruano de a pié, o de todo un país, ello a pesar de "nuestras viejas glorias" que el imaginario popular ha convertido en verdaderos ídolos o héroes de barro, como se puede ver en la historia del fútbol peruano, donde muchas de sus "estrellas" pasaron de la gloria a la caída de famas efímeras. Las derrotas bélicas del s. XIX, como fue el caso de la guerra contra la Confederación Perú - boliviana (1836 - 1839) -de la que vamos a hablar - o la Guerra del Pacífico, contra Chile (1879 - 1883), no hicieron sino ahondar el sentimiento de desmoralización histórica de nuestro pueblo, golpes de los que jamás se ha podido recuperar sicológicamente, por más que se haya apelado al "heroísmo" de quienes dieron su vida en defensa de los intereses de uno u otro bando.

Y ese heroísmo lo vemos ahora tan lejano, muy ajeno a nuestro presente, un "heroísmo" solo comparable a la parodia del náufrago que nada y nada en el mar para terminar muriendo en la orilla; hemos tenido héroes que, sin embargo, y pese a representar ejemplos e inspiración para muchas generaciones, no nos han sanado de las bajezas morales y espirituales que hieren a los peruanos en su amor propio. Muchas veces se ha dicho que a falta de esa identidad con el país que los vio nacer, el pueblo apela a esos héroes verdaderos o ficticios para llenar esos vacíos existenciales que tanto lo agobian. Como ayer sucedía con los caudillos de la época republicana, sucede ahora con líderes políticos, pastores evangélicos, deportistas emblemáticos o salseros de moda. Pero olvida el hombre de a pié que tanto cree en su ídolo de turno que este, por desgracia, es mortal y no es de fierro sino de barro, valga reiteración, y así se acaba la ilusión. Todo pasa pero la incertidumbre sigue persiguiéndolo por 
todas partes. El hombre, pues, no puede pegarse a esos símbolos que se deshacen como un castillo de arena, como lo hicieron nuestros antepasados que creyeron hasta en los errores que cometieron los líderes políticos y caudillos militares que hundieron al Perú Republicano. Los mismos errores que volverían a cometerse en pleno siglo $\mathrm{XX}$, con las desastrosas consecuencias que veremos. Y con ellos se fregó el "ser" nacional y el amor propio del peruano, se jodió el Perú, como se diría, pues nada pudo llenar las carencias afectivas que permitan colmar ese "ser" nacional. Esta es, pues, una identidad malbaratada, peor aún, vejada, al punto de que los mismos hechos violentos que aquí describimos no fueron otra cosa que la secuela de esas decisiones y actitudes políticas inexplicables de personajes o grupos de poder que no supieron encarar, calcular o medir la trascendencia de sus actos. Ahora, la consecuencia de tanta iniquidad se ha convertido en una especie de "karma" para el Perú. No en vano, pues, muchos autores se han quejado ¡con cuánta razón! de este sentimiento adverso y de la sensación de destiempo para los hechos de la historia de este desconcertante país... "¿por qué siempre a destiempo el Perú?", se lamentan algunos estudiosos... y no hay respuesta. Es casi vox populi que para el hombre de la calle e incluso para muchos doctos en estas materias tan "irrelevantes", todo intento de explicación es un viaje a la China, pues por lo general una alusión a tales hechos se convierte en un mutis de indiferencia o en cuestionamientos inútiles. Hay en nuestra comunidad una especie de anorexia mental, una suerte de anestesia colectiva -que cuando a la gente se le habla del punto o se encoje de hombros o expresa su increíble "amnesia histórica" - ; es una retahíla de "olvido" solapado que se pierde en el caos de la alocada vida cotidiana de las ciudades como Lima, que no parecen sentir el ramalazo de esta acuciante falta de recordación histórica. Al peruano siempre se le ha achacado su inacción, así sea ante hechos que lo afectan o involucran; se le ha criticado su incapacidad para indignarse ante la injusticia de tales hechos indignación que seguramente puede tener, pero que prefiere guardársela para la "procesión por dentro"-; mucho se ha cuestionado al peruano por tales comportamientos, pero esto de perder la memoria colectiva es algo que ya raya en la 
estupidez. La indolente actitud de "dejar pasar" sin poner reparos, ese "darle la vuelta a la hoja" sin hacerse preguntas, es en verdad patética, pero muchos olvidan que la "hoja" de marras, para desgracia del colectivo, todavía tiene memoria.

Esta "amnesia" de la sociedad peruana ha sido muy bien descrita por la investigadora Cecilia Méndez G (Nota 4), en una ponencia donde esta estudiosa analiza la reacción de la población ante el recuerdo de los hechos de la violencia política en el Perú durante las décadas de los 80s y 90s del siglo pasado (s. XX), cuando, al hablar del terrorismo de Sendero Luminoso y el terrorismo del Estado Peruano -la llamada "guerra sucia", cuando la intervención armada del Gobierno cobraba víctimas inocentes - , tanto bajo el primer gobierno de Alan García (1985 - 1990) como bajo la dictadura de Alberto Fujimori (1990 - 2000) -cuando la corrupción política y las violaciones de los derechos humanos llegaron a un límite escandaloso-, señala lo siguiente: En el Perú las personas se ven cotidianamente confrontadas con problemas que exigen soluciones inmediatas. Con frecuencia, estos problemas tienen que ver con la supervivencia. Las reflexiones sobre el pasado reciente no abundan, comprensiblemente. Existe una tendencia a olvidar. $\mathrm{Y}$ ya sean éstas las razones, o la dificultad de racionalizar hechos todavía dolorosos, lo cierto es que una cierta amnesia sobre el pasado reciente -aquél marcado por casi una década y media de guerra interna- se constata no sólo entre los historiadores sino, en general, en la población. (Nota 5)

Los pasados remotos suelen ser, en cambio, más fácilmente traídos a colación. Esto se debe no sólo a que son más familiares a nuestro discurso y a nuestra educación sino que se convierten en instancias explicativas más cómodas; nuestra responsabilidad en esa reflexión del pasado está menos puesta en juego por qué hablamos de tiempos distantes; esta distancia libera al que analiza de profundizar más su entorno. Por ejemplo, la expresión "desde hace quinientos años"; o "trauma de la conquista", siguen siendo lugares comunes para explicar problemas como el racismo y la 
violencia política. Pero debido a que se concentran en "un momento decisivo", estos discursos no profundizan el sentido de la evolución histórica en sí misma. La célebre pregunta de un personaje de Vargas Llosa, "¿en qué momento se jodió el Perú?", es un buen ejemplo de esta actitud hacia el pasado. La búsqueda de "un momento decisivo" implica concebir el pasado como un hecho "dado", antes que como una interrogante cuya respuesta debiera renovarse en función de la evolución del presente. (Nota 6)

\section{Palabra de escribidor}

Para algunos autores, el absurdo de estos fracasos históricos data de la época de la Conquista Española, pero que se acentuó después de la Independencia Nacional. Son hechos que parecen haber moldeado el carácter del peruano, parecen haber dado forma al "ego" nacional en un sentido negativo. Desde entonces, cual palo ensebado, una realidad despiadada nos hace resbalar -sino que lo digan los repetidos fracasos deportivos, algo que ya ha sido asumido como "normal" por los peruanos -, o acaso nos enredamos, cual telaraña, para quedar atrapados en la maraña de nuestras incertidumbres, de nuestras peores pesadillas. La pesadilla que implica el eterno retorno al enfrentamiento de peruanos contra peruanos, heredado de conflictos armados o de crisis políticas que muchos historiadores no quieren mencionar o no saben explicar; la pesadilla de no saber el quid de las cosas que parecen tan "estúpidas", tan "irracionales", pero que sucedieron y suceden, y nos dejan marcados para siempre como colectividad. Por ello, la alusión que citamos arriba, ese ¿en qué momento se jodió el Perú? no es nada baldía: nos recuerda que en la psique del pueblo peruano -de todas las clases sociales - aún hay una disyuntiva trascendental, hay un anhelo popular insatisfecho que se convierte en trauma y genera lamentos por lo perdido en tal o cual acontecimiento de relevancia histórica; hay un "no sé qué" latente en el inconsciente colectivo del hombre de la calle que lo lleva siempre a hacerse la misma e inasible cuestión que involucra al "orgullo de ser peruano"; de allí 
la mención a la pregunta que alguna vez se hizo Mario Vargas Llosa a través de uno de sus personajes novelescos, la misma que ha sido tomada desde uno y otro ángulo por muchos autores para reflexionar e investigar el "leiv motiv" reciente y lejano de nuestra incomprendida historia. ¿En qué momento se jodió el Perú? es, a resumidas cuentas, la angustiante pregunta que un personaje de la novela Conversación en la Catedral al recordar la insoportable levedad de de la vida que tiene que llevar sin encontrar una respuesta que le dé un atisbo de paz interior.

Figura 2. Best Seller. Desde su primera edición, en 1969, Conversación en la Catedral no solo es una de las más exitosas novelas de Mario Vargas Llosa, sino que su contenido ha traído una cola muy, pero muy larga. En la imagen, una de las tantas reediciones que se han hecho a esta obra. Ilustración obtenida del sitio Mario Vargas Llosa. La Obra.

El autor de Conversación en la Catedral basó su novela en el tema de la crisis existencial del Perú y de los peruanos, y así lo resalta cuando, durante una entrevista que se le hizo en un conocido programa televisivo de opinión política, expresó lo siguiente: Bueno yo no creo que los países se joden en algún momento, salvo en casos muy excepcionales. Yo creo que la decadencia, el fracaso, los retrocesos de un país son un proceso, algo que va ocurriendo a lo largo del tiempo y cuya responsabilidad recae sobre muchas personas, muchas generaciones.

En el caso de nuestro país, yo no tengo duda que han habido algunos momentos que el Perú tenía una oportunidad y parecía enrumbarse en la buena dirección. Por ejemplo, en 1945, cuando se produce este despertar democrático, asume la presidencia una persona absolutamente impecable, íntegra, como es Bustamante Rivero. Esa democracia fue atacada con ferocidad por una oligarquía que era antidemocrática y por el Apra desde la izquierda. Y entre ambos pues la destruyeron y tuvimos la dictadura militar de Odría. 
El Perú se ha ido pues empobreciendo a medida que iba desechando oportunidades y escogiendo lo peor. Creo que ese es el resultado que vivimos en este momento. Somos un país muy empobrecido, un país que no ha resuelto todavía los problemas básicos y que a pesar de contar con tantos recursos no solo naturales, sino humanos. Es un país pobre, atrasado, de instituciones muy precarias.

Aunque en muchas cosas el Perú ha cambiado desde la época de Odría, en muchas otras por desgracia no. Nosotros, no hace mucho, pues hemos vivido casi diez años una dictadura con el señor Fujimori y el señor Montesinos. Una dictadura que aunque en muchas cosas se diferenciaba de la de Odría, en otras: violencia, represión y sobre todo corrupción.

La división de la sociedad peruana no solamente entre quienes tienen todas las oportunidades y entre quienes no tienen ninguna las diferencias abismales entre la riqueza y la pobreza... todo eso yo creo que le da una vigencia a la novela en cuanto a la problemática política y social. Es una de las novelas, tal vez, que más trabajo me ha costado escribir. Demoré tres años escribiéndola y durante buena parte de esos tres años estuve bastante perdido, confundido sobre cómo darle coherencia. Al mismo tiempo creo que pocas veces he disfrutado tanto un proyecto novelístico en el que hasta el final trabajé con un enorme entusiasmo, una gran ilusión. (Nota 7)

\section{El trauma de la Historia del Perú}

Así como el autor de Conversación en la Catedral se hace esta cuestión tan elemental para la existencialidad del Perú como nación, otros autores han tratado de ir más allá para explicar este entuerto de sentimientos tan contradictorios como difíciles de asumir para el hombre de a pie. Por ejemplo, el historiador Manuel Burga le toma la palabra al escribidor, para responder a una entrevista de Mariela Balbi, una conocida periodista peruana, quien lo interpeló sobre los entuertos de nuestra historia... y 
sobre ¿en qué momento se jodió el Perú? pone a la Guerra del Pacífico (1879 - 1883) y las desavenencias entre dos partidos políticos (civilistas y pierolistas), como una de las causas del porqué se jodió el Perú. He aquí una parte muy reveladora de dicha conversación:

\section{(...)}

¿No es un discurso un poco lastimero decir que nos falta identidad, que no estamos completos como nación?

Es un pesimismo que se explica bien en la expresión de Zavalita "¿en qué momento se jodió el Perú?", cuándo se perdió el rumbo de la historia, el paso? Esa sensación nos habita. También se presenta porque el Perú fue un gran imperio indígena, una gran organización colonial y una república tan "fuerte" que fue necesario que los ejércitos libertadores coincidieran aquí para liberarnos. A partir de ahí comenzó la merma. Los siglos XIX y XX son periodos en los que el Perú parece recogerse, retraerse. ¿Cuándo realmente el Perú perdió su paso?

¿En el siglo XIX, después de la guerra con Chile?

Pareciera que sí. Perdimos la guerra con Chile, una provincia periférica -que era una capitanía general - nos derrota militarmente. Algo ya había pasado entre 1821 y 1870. Lo que sucede con la guerra con Chile se va profundizando. Mientras que Chile y México parecen acelerar su historia, el Perú parece sostenido por la República Aristocrática, entre 1895 a 1915. Hay una serie de sensaciones objetivas que nos hacen pensar que el Perú se atrasó en la época republicana.

El conflicto con Chile nos agarró en una desunión total. La frase "antes los chilenos que Piérola" es terrible y escalofriante... 
La Independencia creó el primer militarismo y el enfrentamiento de facciones y de la sociedad civil. Previo a la guerra con Chile, durante el gobierno de Manuel Pardo, el enfrentamiento fue muy fuerte entre civilistas y pierolistas. (Nota 8 y Nota 9)

¿Por qué se odiaban?

Por la disputa del poder y por la de las fuentes de generación de riqueza, entre ellas el guano. Esa frase es la bancarrota de un proyecto de nación, no había una vinculación con el colectivo llamado Perú. Luego de la guerra, los enfrentamientos entre Andrés Cáceres y Miguel Iglesias fueron terriblemente sangrientos, contribuyeron al debilitamiento posterior del Perú. La reconstrucción tuvo mucha dificultad porque los antagonismos duraron desde 1883 hasta 1894, cuando el movimiento popular sacó a Cáceres del gobierno. Fue un periodo de pérdida de tiempo para el país, de luchas intestinas y conspiraciones.

¿Cuál era el discurso político de Mariano Ignacio Prado, quien estuvo en el poder durante la guerra?

Pardo fue asesinado y Prado lo sucede. El civilismo quería una nación moderna, integrada. Pardo tuvo como vicepresidentes a representantes de las regiones del Perú, un puneño y un cusqueño; era un gesto descentralista. La tendencia era ir fortaleciendo a las regiones en el Estado Central, la llamaba "la república práctica". Los civilistas adquirieron poder con la consignación del guano, mientras que los pierolistas buscaban mayores beneficios económicos de la gestión del Estado. Por razones de rentabilidad económica, Piérola entregó el guano y otras cosas a los capitales extranjeros -entre ellos a Auguste Dreyfus - reemplazando a los consignatarios nacionales. La guerra con Chile nos encontró en medio de una mala gestión del Estado y una guerra fratricida entre peruanos. 
Efectivamente, para los políticos de la época eran más importantes sus diferencias que el progreso del país y esta desunión definitivamente fue una de las peores debilidades de nuestros antepasados durante la guerra con Chile del siglo XIX. Y por eso el atraso de nuestro país. (Nota 10)

\subsection{Al grano... ¿qué quiere decir jodió?}

Jodió es la tercera persona del singular del pretérito indefinido del verbo joder.

El significado de esta popular acepción va según el país, en Perú, por ejemplo, la palabra jodió es una forma de decir en el habla común: jodido.

El Diccionario de la Lengua de la Real Academia (22 $2^{\text {a }}$ Edición) menciona, por su lado, la palabra joder, bajo los siguientes términos:

joder.(Del lat. Futuere).

2.Tr. Molestar, fastidiar. U. t. c. int. y c. prnl. 3. tr. Destrozar, arruinar, echar a perder. U. t. c. prml.

joder. 1. interj. U. para expresar enfado, irritación, asombro, etc.

Por su parte, Guillermo E. Bendezu Neyra, en su obra: "Argot Limeño o Jerga Criolla del Perú" (Nota 11), señala que en el Perú son muy usuales las voces joda, joder y jodido. En cuanto a la primera de estas (joda), es una acepción que, según Bendezu, significa: preocupación constante ó privación constante de algo/ ... todo es una joda: que la matrícula, que el permiso de cachaco (cachaco, sin. de licencia de conducir), 
que la parabrisa (el ingreso en la universidad), ya me tiene huamán... (huamán, sin. de harto, molesto); en lo que se refiere a la segunda voz (joder), el autor describe tres acepciones, una de las cuales es sinónimo de perjudicar o dañar, así se dice: si no pagas la multa te pueden joder: mejor es darles gusto y no embarrarse con vainas... (vainas, en Perú implica problemas, preocupaciones, ser insistente; finalmente, en la última de estas voces (jodido), el autor ha identificado cinco acepciones, una de estas es sinónimo de desafortunado, infeliz/... eres un jodido de primera; no me explico por qué te encuentras hasta el uin... (uin, sin. de amigo inseparable)

Nota: Hemos creído conveniente agregar notas de redacción a este texto entre paréntesis, a modo de aclaraciones, debido a que el autor arriba citado se remite a la jerga limeña para explicar los significados que alude.

\section{El Perú que nos dejó la cruel paradoja de Yungay... y una dictadura militar}

De todos los intentos de explicar el quid de la coyuntura peruana sobre su trama existencial, tal vez el mejor logrado ha sido el reportaje que el insigne periodista peruano Francisco Igartua Rovira (n. 1923 - m. 2004) hizo sobre el tema inicial de la obra Conversación en la Catedral: la sempiterna pregunta de ¿en qué momento se jodió el Perú? El fundador de la desaparecida revista Oiga, uno de los medios de opinión política más prestigiosos e influyentes de Sudamérica, redactó aquí un análisis histórico donde se puede apreciar la profundidad, la agudeza y la visión de sus reflexiones en torno a una realidad tan ancha como inasible: el Perú. Cuando puso a la venta el último número de su recordada revista, el 5 de setiembre de 1995, en sus páginas apareció aquel reportaje que hizo historia, y fue motivo para interminables debates. (En 10. Recortes de Prensa, en el subcapítulo 10.2., el lector podrá encontrar el texto completo del reportaje ¿En qué momento se jodió el Perú?) Se trataba de un maravilloso alegato sobre la historia reciente del Perú que pretende 
responder a las inquietudes acerca del drama subyacente del Perú. Su contenido revela con pruebas al canto las razones ocultas de la debacle moral y espiritual del peruano. Lo que sigue a continuación es la re-edición de un análisis del tema tratado por el maestro Igartua, redactado por el autor del presente trabajo El Perú y las paradojas de Calimero.

\section{1. ¿En qué momento se jodió el Perú?}

Buscando una respuesta a las carencias existenciales del Perú como nación, y el porqué de su desconcertante realidad presente, el maestro Igartua recurre a nuestro pasado, con la esperanza de encontrar en algún recoveco la anhelada solución (o una conclusión que invite a buscar opciones más favorables) al término que nos ocupa: ¿en qué momento se jodió el Perú? Paco Igartua escribe, antes de ir al grano, y tras una breve introducción, estas líneas que le servirán de guía para indagar en el ayer lo que poco mencionan los libros de historia, en busca del eslabón perdido de nuestro pasado: "...bueno es mirar hacia atrás, a releer lo ya escrito. En estos días en que la economía nacional va abriendo posibilidades insospechadas de desarrollo, a la vez que va creciendo el hambre y la desocupación -la miseria en sus distintas tonalidades- y se comprueba cómo va el Estado fagocitándose a todas las instituciones -Igartua se refiere, claro está, al régimen de Alberto Fujimori, bajo cuya gestión Oiga libró una desigual batalla contra aquella dictadura corrupta - , llevando al país a un centralismo agobiante, que la mayoría acepta por inercia o por ignorancia de lo que éste significó en nuestra historia y en la de otros pueblos; en estos días tan contradictorios y tan difíciles de analizar con sosiego, no hay mejor manera de hallar algo de luz que mirando al pasado, hurgando en las lecciones del ayer alguna explicación a los desconcertantes hechos de la palpitante actualidad." Luego, tras un previo análisis explicativo para ubicar al lector en el contexto de los hechos, en el escenario de las coyunturas políticas peruanas antes de aquel siglo XX y lo que vino después, la primera de sus conclusiones es que la causa del desaguisado no estuvo en 
el incario; por tal motivo, en aquella época el Perú no se jodió "porque entonces estas tierras eran apenas embrión de un país no nacido"; tampoco fue en la Colonia, pues aquellos "eran tiempos en que la historia no existía fuera de los mares europeos -que abarcaban las aguas del mundo- y cualquier país de la periferia europea, cercano o lejano a aquella historia, estaba en el limbo, no tenía un porvenir señalado (aunque no sería ocioso apuntar de paso que los virreinatos de México y el Perú eran entonces los territorios más desarrollados de toda América)". Cuando el "repaso histórico" llega a las "primeras repúblicas" del siglo XIX -lo decimos así porque entre las guerras de la Independencia del Perú (1820 - 1824) y la época de "la falaz prosperidad del guano de las islas" (1842 - 1866) hubo varios gobiernos democráticos, varios golpes de Estado y varias constituciones políticas, tan disímiles unas de las otras, y varios "volver a comenzar" - , el maestro Igartua se detiene ante un hecho que para él tuvo mucho que ver en la formación de nuestra idiosincrasia, al relatar... "Aquí ya se trata de nuestros días y de nuestras responsabilidades. Sin embargo, los primeros decenios de vida independiente transcurren por igual, con similares rivalidades entre caudillos, en toda América Latina; sin que Lima dejara de ser en esos años la capital más importante de América del Sur. Hasta esa etapa, las posibilidades de desarrollo para la incipiente nación peruana eran iguales o mayores que las de Colombia, Chile o Argentina. Nuestro primer gran contratiempo recién llega a mediados del siglo pasado (s. XIX. N. de. R.) y es obra de peruanos. Son los peruanos desterrados en Chile, con el futuro mariscal Castilla a la cabeza, los que alientan la expedición chilena que en Yungay derrota y destruye a la Confederación Perú-boliviana, creada por Santa Cruz con la visionaria intención de corregir el despechado despropósito de Bolívar y rehacer el territorio histórico del Perú. Es imposible desde hoy, desde nuestro trágico presente, vislumbrar lo que hubiera sido la reunificación peruana, esa república que soñaron algunos espíritus visionarios, ese Perú que pudo ser y no fue. De todos modos, si hubiera sido un territorio más grande y más rico, con una Sierra más potente frente a la lánguida y amodorrada Lima -ciudad cuyo nombre tiene fragancia de fruta asexuada-; y quién sabe si de ahí, de un diálogo vital entre la Costa 
y los Andes, hubiera surgido la nación que aún no logramos forjar. Pero la historia no se hace con lo que pudo haber sido y no fue. No podemos, por ejemplo, adivinar siquiera el Perú que hubiéramos heredado de las rebeldías de Gonzalo Pizarro o de la enloquecida correría de Lope de Aguirre por selvas, cordilleras, ríos y mares en búsqueda del reino de la libertad, que él quiso ubicar en tierras del Pirú. La historia es hija de los hechos, de lo ocurrido y constatado. No es de la imaginación ni de los deseos. Puede sí serla de los olvidos. Es historia, por ejemplo, la glorificación en el Perú del mariscal Castilla y también es historia la canción que a diario se escucha cantar a los niños en las escuelas de Chile:

$$
\begin{aligned}
& \text { "Cantemos la gloria } \\
& \text { del triunfo marcial } \\
& \text { que el pueblo chileno } \\
& \text { obtuvo en Yungay..." }
\end{aligned}
$$

Son, en realidad, la misma historia. Pero mientras en un lado -en Chile- se tiene memoria correcta de lo que fue un hito importante en la formación de su país como nación, en la otra parte -en el Perú- ni siquiera se recuerda que fue Castilla quien capitaneó esas huestes chilenas, destructoras de la Confederación que reunificaba al Perú que Bolívar dividió por vengarse de los desprecios de Lima." 


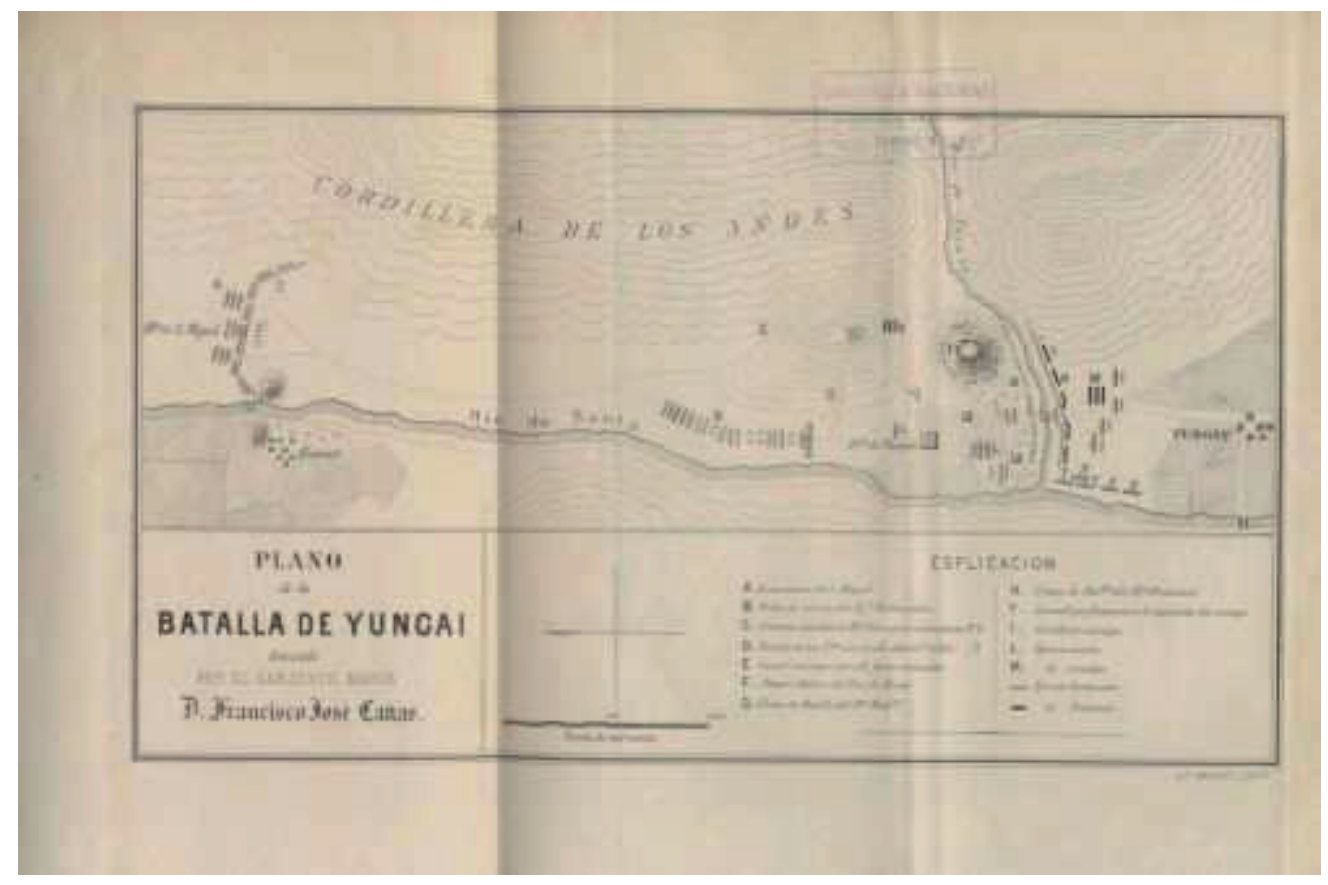

Figura 3a. Mapa de la Batalla de Yungay, diseñado por el sargento chileno Francisco José Cañas, uno de los protagonistas de este enfrentamiento, y publicado en la obra Historia de la Campaña del Perú en 1838, por Gonzalo Bulnes. Santiago de Chile: Imprenta de "Los Tiempos", 1878.

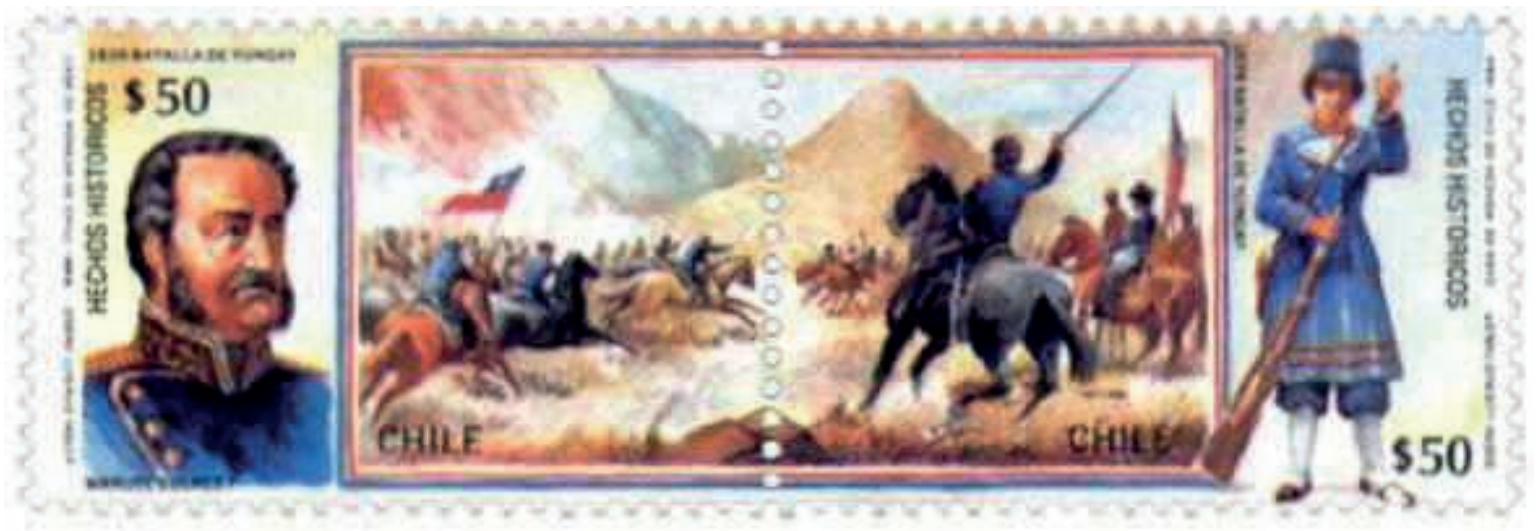

Figura 3b. Sello chileno conmemorativo de la batalla de Yungay, con un curioso retrato del general Manuel Bulnes. Ilustración del portal chilecollector.com 


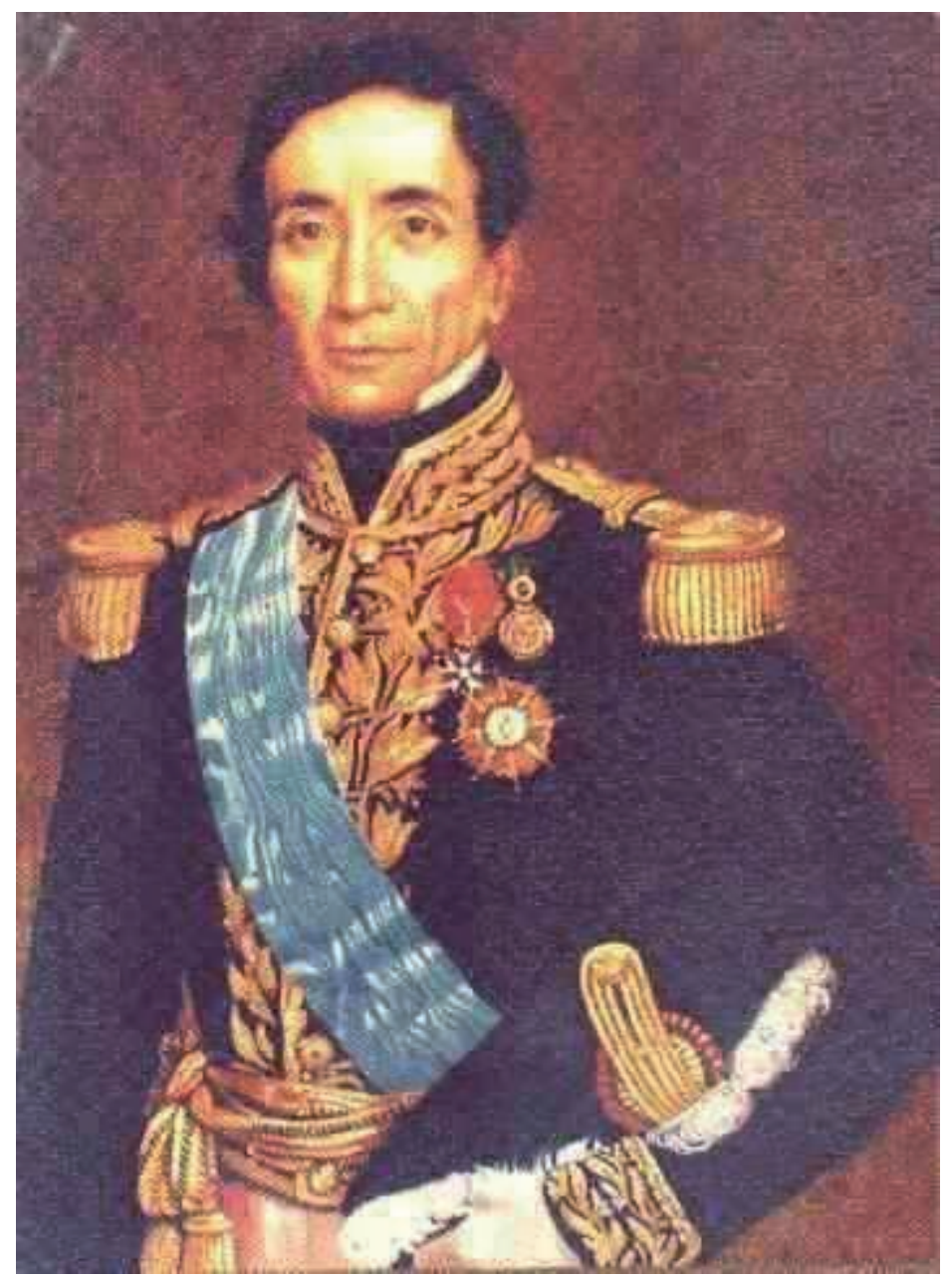

Figura 4. El general Andrés de Santa de Cruz (n. 1792 - m. 1865) en un retrato de época, luciendo el uniforme de Gran Mariscal. Ilustración del portal de la Escuela de Comando y Estado Mayor del Ejército de Bolivia.

Más abajo, Igartua hace un paréntesis respecto al descalabro de la Guerra del Pacífico cuando señala que la pérdida de la guerra no es que nos haya postrado en lo más bajo, sino que nos devastó como nación... "Lo hizo caer en el abismo de la ruina económica y moral. Y, en este caso, la humillación nos abrumó hasta tal punto que se ha hecho obsesión nacional su recuerdo. Lo que tampoco es sano ni fecundo". Aunque luego de este infausto conflicto vino un periodo de reconstrucción nacional, las secuelas de esta derrota y la de Yungay, ambas a manos de gente venida del sur, 
parece habernos marcado como pueblo, de alguna forma, y aleve... por eso Igartua nos dice:

"Sin embargo, a pesar de esos dos tremendos desastres, no fue entonces que el Perú se jodió. Con tenacidad, con esfuerzos propios, con confianza en el destino patrio, el Perú se recuperó y, a finales del siglo pasado y comienzos del novecientos, florecía nuestra agricultura y la minería peruana respaldaba una moneda que iba "a la par con Londres. Todavía no eran los tiempos del dólar, reinaba en aquella época la libra esterlina." Más adelante, Igartua se detiene en la llamada "República Aristocrática", período que significó una de las primeras frustraciones colectivas provocadas en el siglo XX por el maquillaje demagógico de los políticos para hacer creer al pueblo que todo andaba bien, pero que tuvo un penoso epílogo para la dictadura de Augusto B. Leguía. "A pesar de la dictadura y el centralismo leguiísta, no había llegado la hora en que se jodió el Perú", escribe Igartua. Para el autor tampoco se le puede echar la culpa al "crac" de la bolsa neoyorquina de 1929, a pesar de que este desastre económico provocó cierres de empresas y gente menesterosa deambulando por las calles, o a las dos guerras mundiales -pese la fugaz bonanza en el Perú por la exportación de los minerales, que las naciones en conflicto necesitaban-, o el accionar del APRA, que pugnaba por llegar al poder a toda costa, o a las dictaduras de Prado y Odría (aunque estas últimas en algo influyeron en nuestro devenir histórico reciente). El autor dirige, entonces, sus baterías al gobierno militar de Juan Velasco Alvarado, tras el golpe de estado del 3 de octubre de 1968, y sus medidas "revolucionarias", así como al primer gobierno de Alan García.

Al hablar de esta dictadura militar, el maestro Igartua dice que aquí "sí es cuando se jodió el Perú. No porque fuera innecesario enterrar el pasado. Era necesario hacerlo y bien enterrado debiera estar. Era necesario abrir la sociedad peruana. Al Perú lo ahogaba una argolla medieval, una oligarquía despiadada en los negocios y cerrada, ciega, en lo social, sin aliento patrio, sin visión de futuro, ignorante de las nuevas 
ideas que se iban imponiendo por el mundo, huérfana de respuestas a las exigencias de la hora. Sin darse cuenta de cómo ni cuándo la clase dirigente peruana se había convertido en cadáver que caminaba, hablaba y hacía dinero explotando a otros, no por habilidad propia, sino gracias a una especie de quinto real, de monopolio concedido a ella por gracia divina." El golpe de Velasco, pues, es visto como la medicina, pero el remedio, a la larga, resultó ser peor que la enfermedad, pues las medidas que adoptó el "Gobierno Revolucionario" para reformar las instituciones peruanas y la administración pública se fueron por la tangente... y el Perú acabó siendo pasto del autoritarismo. Por ello, Igartua explica que "el Perú se jodió con el gobierno militar" en aquellos años, porque el país se apartó de la integración nacional y se pretendió aplicar un modelo ya fracasado en otros países del mundo, como fue el caso cubano. En este contexto, el gobierno militar no sólo no tenía idea de lo que iba a hacer cuando tomó las riendas del poder sino que con sus propuestas "revolucionarias" creó una ilusión dentro de la ilusión socialista. 


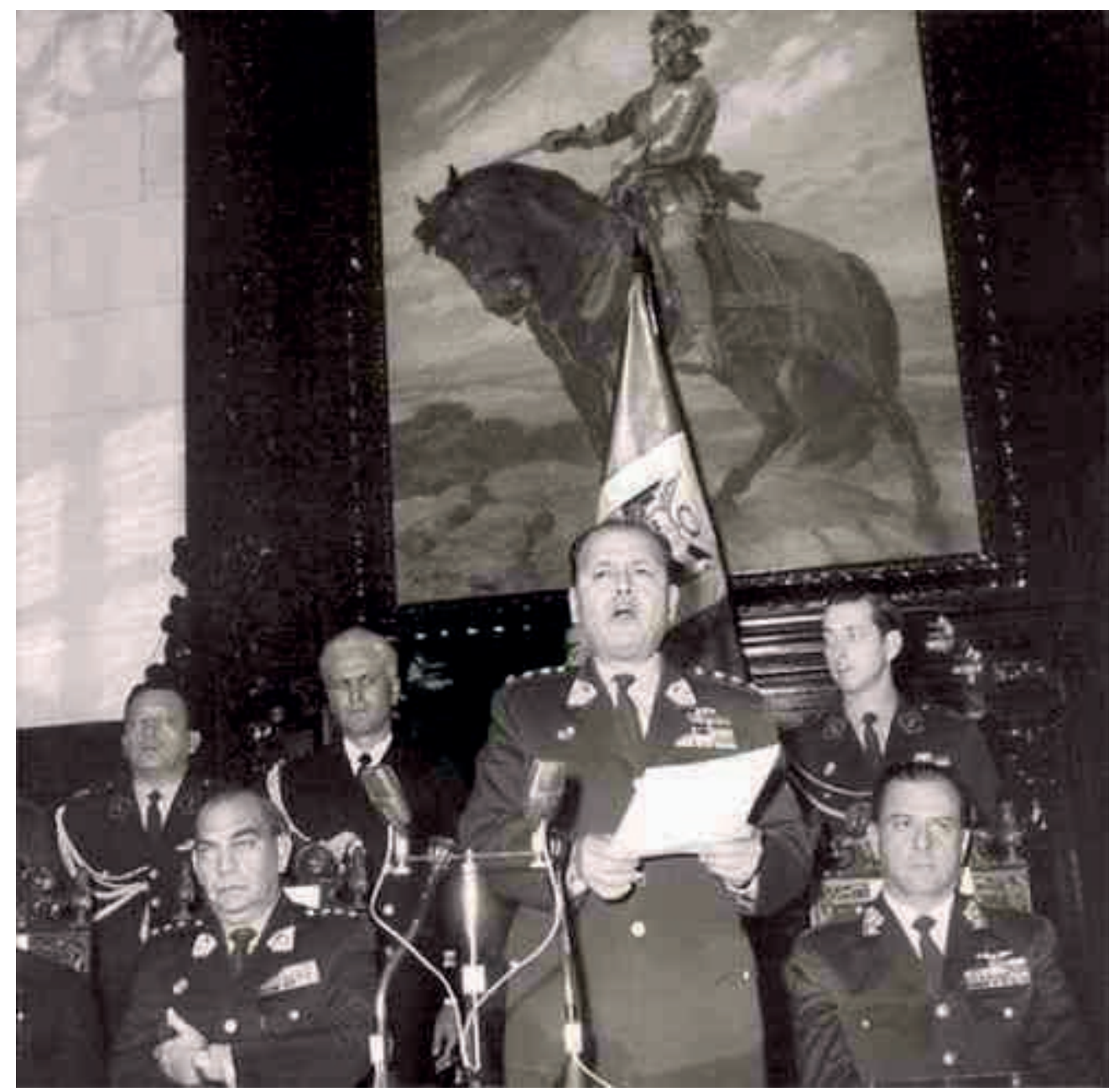

Figura 5. Foto del general (r) Juan Velasco Alvarado leyendo su histórico discurso del 3 de octubre de 1968, tras la violenta madrugada que acabó con el primer gobierno de Fernando Belaunde Terry; aquel día marcó el inicio de una dictadura militar de casi 12 años. El Perú ya nunca volvería a ser el mismo. Imagen obtenida del blog pospost.blogspot.com

Pero lo peor vino con la ejecución de su proyección social, que no encaró el problema del indio como parte integral de la nación peruana, sino que lo marginó: "De este modo, la inevitable crisis económica estalló en conflicto social y el problema del indio, aunque sufriera algunos cambios, más aparentes que reales, quedó en lo mismo: siguió siendo la gran traba al desarrollo social del Perú. (...)" Por esta razón, el Perú no "se jodió porque en esos años se dieron pasos firmes hacia la integración 
peruana. No. Acelerar el paso en esa dirección era necesario para que el país fuera, por fin, adquiriendo conciencia de nación, para que los peruanos entendiéramos qué es sentido nacional. Ya que no es posible hablar de nación peruana mientras el indio, el indígena de estas tierras, no se halle incorporado, junto con los demás peruanos, a la actividad del hombre moderno; mientras no lleguemos a entender que la rabulesca eliminación de la palabra indio en el diccionario peruano no elimina -ni siquiera esconde- el problema del indio. (...)." El Perú, en efecto, se fue al tacho justo cuando el velasquismo y todo su tinglado osaron tocar las fibras más sensibles de la andinidad; y esto sucedió precisamente en el momento en que se quiso negar sus raíces, ignorando que la población peruana es mayormente andina; y se fregó cuando se pretendió rechazar que la mayoría de la población peruana habla quechua o aimara, se desconoció que fueron nuestros ancestros de las viejas culturas los verdaderos creadores de la identidad nacional, y no, como se quiso atribuir, a los "blanquitos de la costa"; entonces "por no mirarlo o por despreciar al indio" fue que ocurrió una debacle como el desastre de Yungay. Ese fue el contagio de la estrecha visión limeña de los Andes que, cual enfermedad, pasó al gobierno de la Junta Militar, lo que después hundiría al país en un estado de constante zozobra social.

En el Perú de la "revolución", uno de los errores más graves fue, a juicio del autor, optar por un estatismo cerrado en lugar de fomentar la apertura democrática y la unión nacional que permita el desarrollo de los pueblos. La polarización política del país, la confrontación y el enfrentamiento de clases acabaron creando un ambiente general totalmente enrarecido entre peruanos. El odio de razas, la incomprensión hacia la realidad nacional y la incapacidad para sumarse al mundo moderno, ignorando que el colectivismo había fracasado en otras partes -no hablamos aquí de populismo-, hicieron el resto. Dentro de este escenario, como señala el autor, se generó un socialismo "parecidísimo al que, junto a un tenso enfrentamiento racial, quiso imponer el presidente Alan García. Como si sus principales consejeros fueron 
los mismos jóvenes marxistas que inspiraron los traspiés militares de los años setenta."

Fue dentro de este mismo marco, y por las políticas mal aplicadas, que la "Reforma Agraria" se convirtió en una tragedia humanitaria de dimensiones sin precedentes. En poco tiempo se empobrecieron y despoblaron los campos -lo que no se veía desde el siglo XVI-, lo que provocó una migración de las chacras a las ciudades nunca antes vista, al punto de que la población de Lima se multiplicó por cuatro y muchas ciudades de la Costa se rodearon de barrios llenos de miseria. Si bien es verdad que la intervención estatal agraria era necesaria -esto es lo que estaba haciendo el régimen acciopopulista de Belaunde-, también es cierto que "la situación en la Sierra no ha variado (estamos hablando, claro está, de 1995) en cuanto a productividad -los reformistas no se ocuparon de alentar y orientar al campesino- y si bien han desaparecido los latifundistas, no faltan otros explotadores en su reemplazo." La reforma agraria no fue, pues, la modernización del campo que tanto se pregonaba, aquello de "que el patrón ya no comerá más del sudor de tu frente" fue un engaño, y todo se redujo a una "repartija de tierras. También hubo despojo de herramientas, maquinarias y casas- habitación. Significó la parálisis de la propiedad agrícola, porque la tierra dejó de ser un bien útil para financiar la actividad agrícola, para crecer y prosperar. La tierra sólo sirvió para vegetar en ella." Con la "Reforma Agraria", entonces, la producción no aumentó sino que bajó y continuó bajando -por lo que se tuvo que depender de la importación de alimentos básicos como el arroz y la harina, producidos en sus buenos tiempos en el Perú - , lo que generó la escasez de otros productos como la leche y los cereales. 


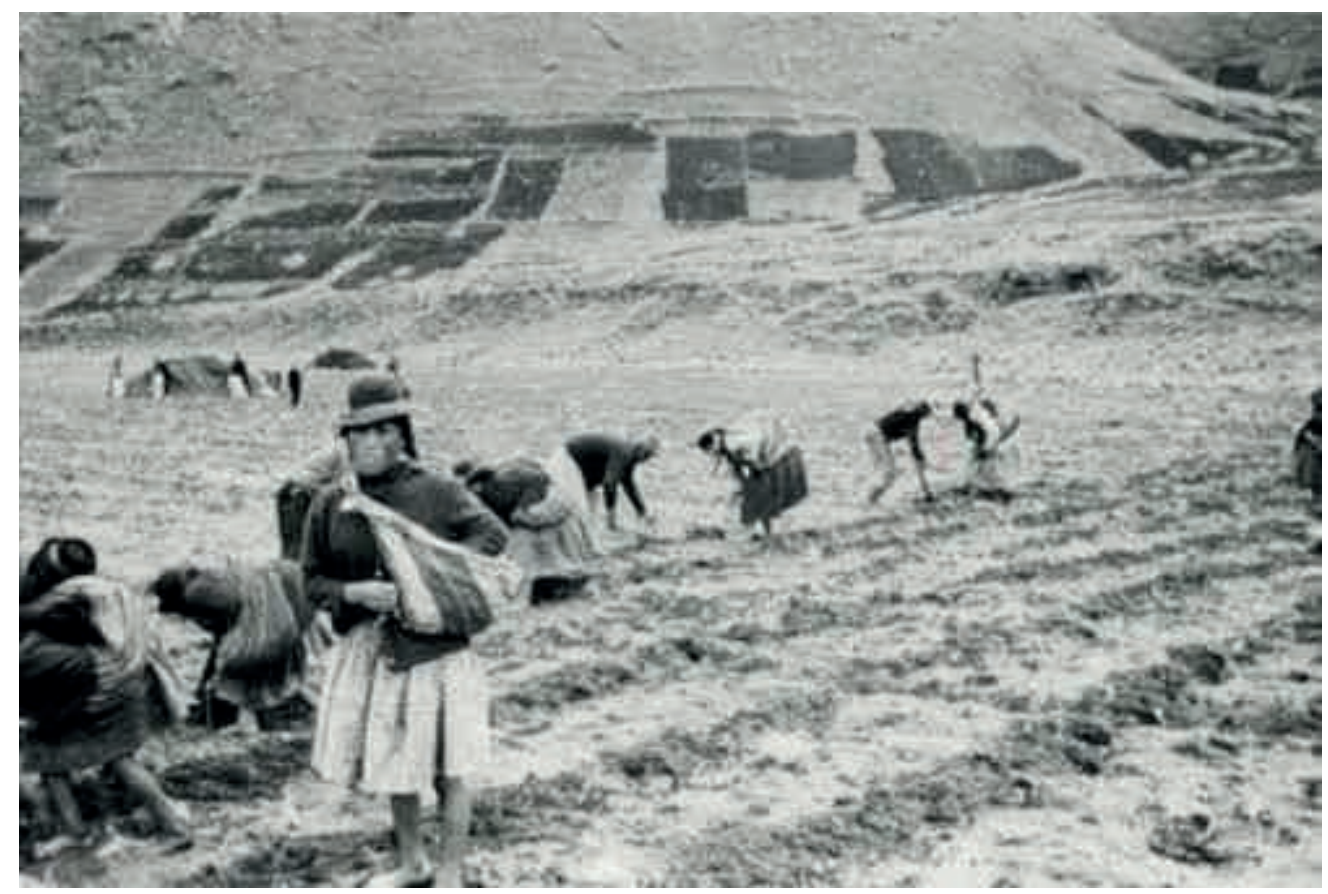

Figura 6. Campesinos de Anta en faenas agrícolas. Luego de la promulgación de la Ley de la Reforma Agraria en 1969 por el General Velasco Alvarado, se inició una nueva etapa de la lucha campesina por la recuperacion de las tierras de sus antepasados. (Archivo CADEP, JMA) (Sic). La leyenda de la foto, por cierto, no coincide con el atroz empobrecimiento del agro que causó dicha "reforma". Sin tierras, sin comida y sin futuro, los habitantes del ande llevaron su hambre a las llamadas "barriadas" o cinturones de miseria que rodearon Lima y otras ciudades del litoral peruano. Gracias a esta migración, la capital peruana se volvería más provinciana que nunca. Imagen del portal de la Coordinadora Nacional de Radio.

Junto con el estatismo y la "Reforma Agraria", otros conceptos se sumaron a las que para Igartua fueron causales de la coyuntura materia de este análisis. Uno de ellos fue la conocida "Comunidad Laboral", una propuesta que estaba muy bien cimentada y buscaba la armonización hombre-trabajo, pero, como diría el maestro, "una cosa son los cálculos en el papel y otra la realidad. De modo que tan buenas intenciones" se pensó que era el sustituto del sindicato - naufragaron, "constituyéndose en un añadido a las trabas que desalientan la producción." Otra medida fue la ley de 
Estabilidad Laboral, también bien intencionada, pero terminó empedrando el infierno, como señala Igartua, pues, "en lugar de aumentar los puestos de trabajo que era lo que se pretendía- éstos fueron disminuyendo. $Y$, peor aún, esa disposición sirvió para destruir con suma eficacia la disciplina en los centros de trabajo." Igartua relata aquí que ya no había, pues, normas sobre horarios de labor y horas de descanso, que todo se hizo según el libre albedrío de cada empresario o empleador. Fueron medidas "revolucionarias" que se aplicaron más mal que bien, y todas contagiaron, como ya dijimos, con la misma enfermedad ya no sólo al gobierno sino a todo el pueblo, donde afloró el resentimiento y la mediocridad, a la vez que la administración pública pasó a estar en manos de holgazanes. El maestro concluye, entonces, que aquí es o fue "que se jodió el Perú. Fue entonces -dice Igartua - que el país comienza a desintegrarse, justo cuando la repartija se hace norma y el socialismo rampante de los cafés latinoamericanos en Europa se hace meta."

Pero de todos los desatinos de la dictadura militar de Velasco Alvarado, el peor fue de tipo social: no encarar con justicia el problema del indio. Para Paco Igartua, más que la "Reforma Agraria", el quid de ¿En qué momento se jodió el Perú? estuvo aquí. Este sería el penoso corolario de una gestión que sumó sus propios desastres -o su gran desastre en conjunto- al que arrastramos desde el primer tercio del siglo XIX, cuando el descalabro de Yungay, porque "-hay que decirlo de una vez- lo que se enseña en las escuelas, lo que opina don Jorge Basadre y lo que nos escribe un lector amable sobre Santa Cruz y la Confederación Perú-boliviana es un engaño que encubre, esconde, maquilla la verdad. Una verdad que, por ser muy amarga, no es agradable reconocer. Pero que es verdad."

Así pues, recordémoslo, querido lector, nuestro primer gran trauma nacional no fue para nada otro evento trágico sino una cruel paradoja: la destrucción de la Confederación Perú-boliviana que en ese entonces lideraba el general Andrés de Santa Cruz. No es dable echar la culpa a Ramón Castilla, que fue un gran estratega, o 
a Agustín Gamarra, un gran estadista (Nota 12), sino a los propios peruanos que participaron en esta desgraciada gesta; los peruanos que marcharon junto con los chilenos en aquella Segunda Expedición Restauradora al Perú (1839), al mando del general Manuel Bulnes, cabeza del Ejército de Chile, y el propio Gamarra, que desde el exilio se había unido a ellos para marchar contra los confederados de Santa Cruz. Fueron estos peruanos quienes terminaron empujando al Perú al abismo en las quebradas de Yungay. Y todo empezaría por la torpeza de nuestros políticos, de nuestra diplomacia, quienes, despistados, "no vieron, ni siquiera olfatearon, lo que ocurría bajo los hechos que ellos vivían apasionadamente. Fueron políticos tan torpes que creyeron posible la anexión del Perú por Bolivia (cuando debió haber sido al revés, pues el Alto Perú fue parte del virreinato peruano). Tremenda equivocación imperdonable en quienes se estimaban estadistas-, alentados por Chile, país que sí veía un peligro para él -para su expansión- en la Confederación." Igartua da a entender, pues, que a Castilla y Gamarra se les puede atribuir, entonces, "los méritos y honores de la derrota que sufrieron en Yungay los confederados del indio Santa Cruz", quién, presidente de Bolivia él, había ingresado al Perú para combatir a las tropas del general Manuel Bulnes, pero invadió Lima sin cruzarse con los chilenos (1836), donde se proclamó "Protector Supremo" de la Confederación Perú - boliviana, pero fue rechazado por la sociedad limeña, que lo repudió por no ser blanco. Entonces, prosigue Igartua, "Al jefe chileno de la expedición, general Bulnes, sólo le correspondió -para desgracia nuestra- la victoria política." Otra cosa que ignoran los peruanos es que con esta victoria se cumplieron los planes de Diego Portales, aquel gran estadista chileno que acogió a los deportados peruanos que luego marcharían bajo mando sureño -Pues Portales, astuto él, no inmolaría a sus paisanos sino precisamente a esos refugiados peruanos que alguna vez recibió y que luego enroló en su ejército contra la Confederación (Nota 13), en "las dos expediciones restauradoras que culminaron en Yungay. Planes y estrategia detalladamente explicados en la carta de Portales que reproduce Jorge Basadre y que en un párrafo dice exactamente: "va usted, en realidad -le escribe Portales a Blanco Encalada, jefe 
de la primera expedición-, a conseguir con el triunfo de sus armas la segunda independencia de Chile... La posición de Chile frente a la Confederación Perúboliviana es insostenible. No puede ser tolerada ni por el pueblo ni por el gobierno porque ello equivaldría a su suicidio. No podemos mirar sin inquietud y la mayor alarma la existencia de dos pueblos confederados y que, a la larga, por la comunidad de origen, lengua, hábitos, religión, ideas, costumbres, formarán, como es natural, un solo núcleo".

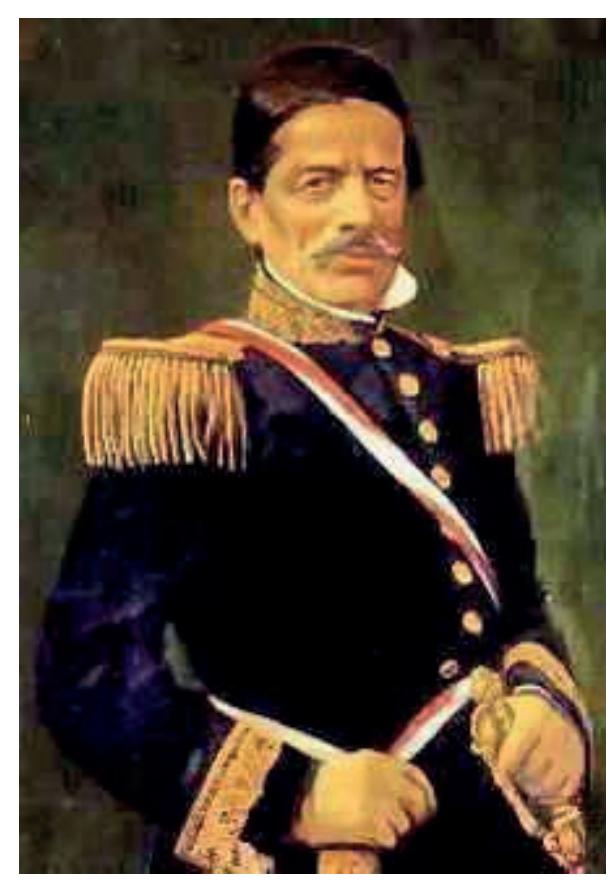

Figura 7. El Gran Mariscal Ramón Castilla y Marquezado (n. 1797 - m. 1867), dos veces presidente del Perú. Óleo del Museo de Historia Militar del Perú, Castillo del Real Felipe, Callao. Ilustración de Wikipedia. 


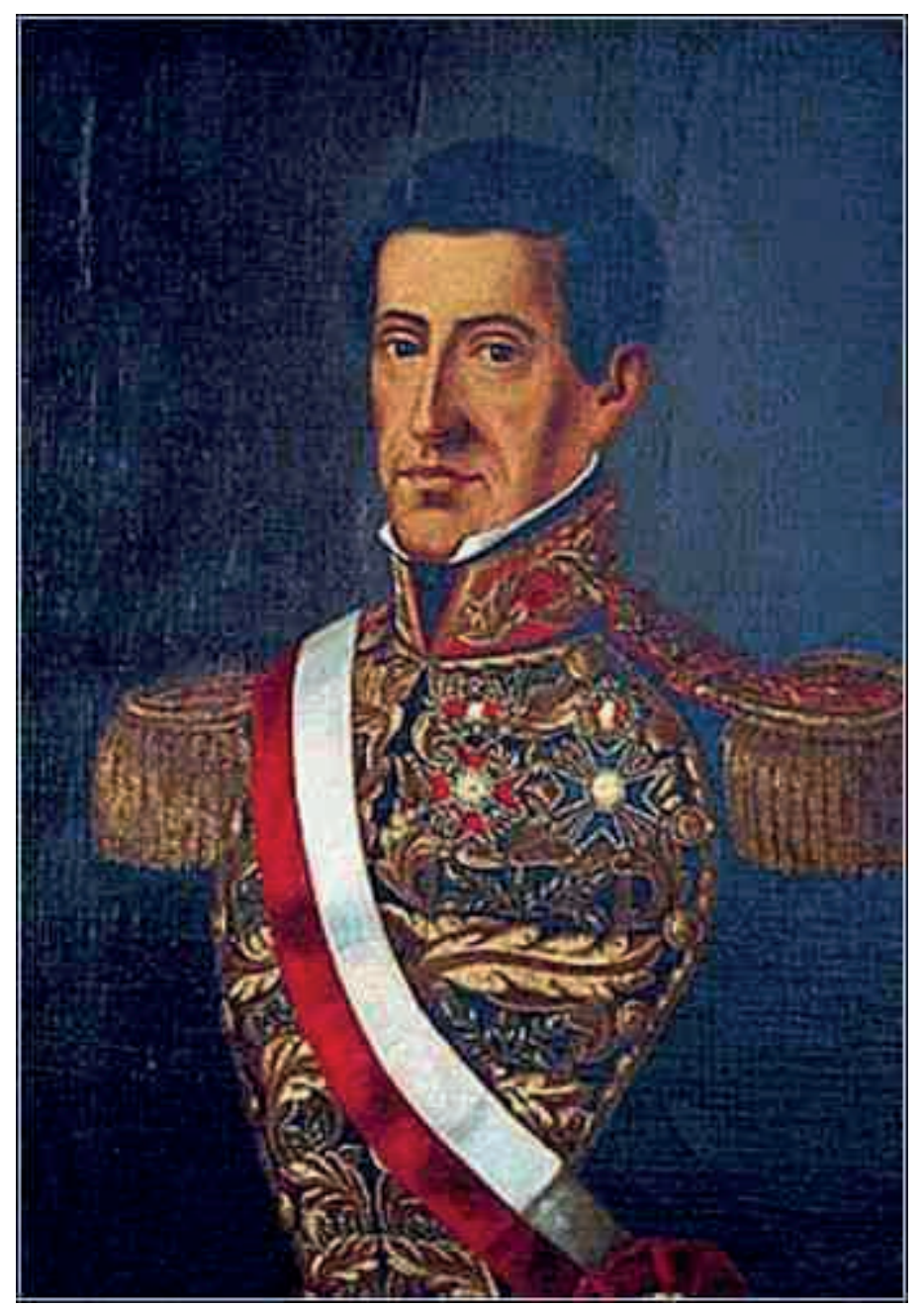

Figura 8. Agustín Gamarra Mesías (n. 1785 - m. 1841) Retrato de época. Ilustración de Wikipedia. 


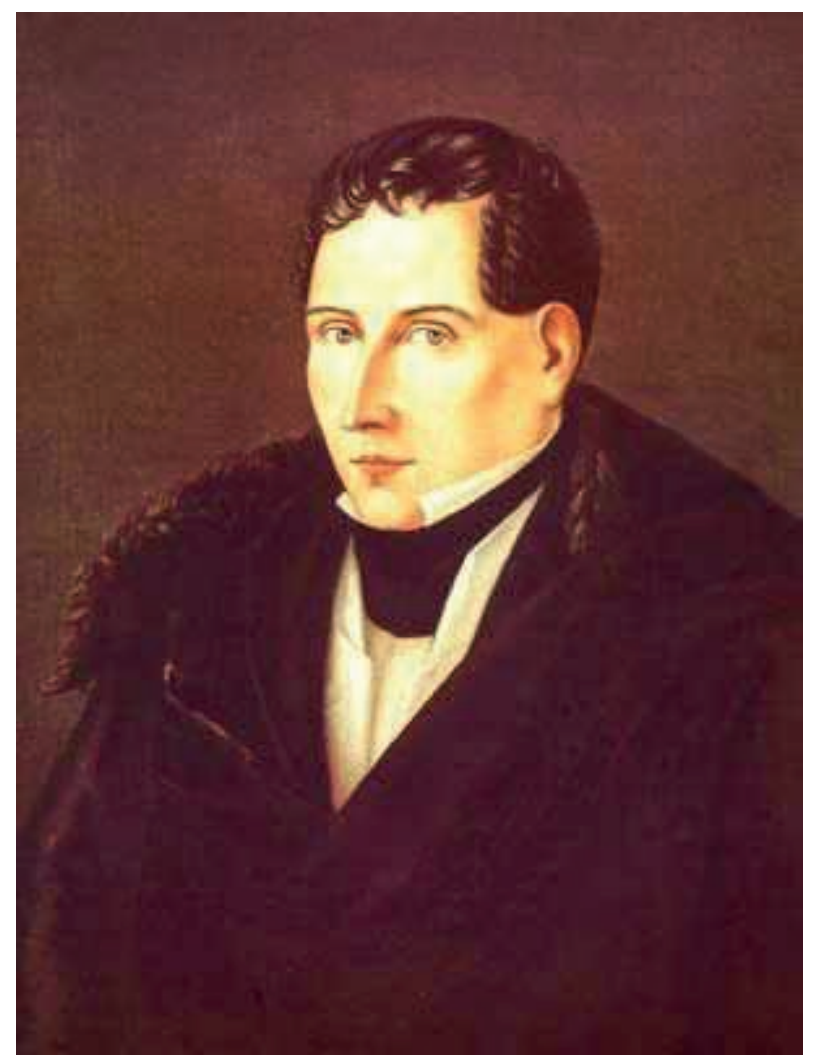

Figura 9. Diego Portales (n. 1793 - m. 1837), el padre de la nación chilena. Óleo de época. Ilustración del blog Alejandro-historiaybiografia.blogspot.com

Para Paco Igartua, la astucia de Portales fue mucho mayor que la de los políticos peruanos y supo vislumbrar el horizonte que no veían nuestros caudillos de entonces -con Castilla a la cabeza y Santa Cruz, que finalmente sería el gran sacrificado-; también pudo adivinar aquello que no supieron entrever los acomodados integrantes de la diplomacia peruana, y menos aún la sociedad heredera de la virreinal Lima, más preocupada por su vida muelle y feliz que por otra cosa; tampoco lo comprendieron en su medida los historiadores que han tocado este triste acontecimiento, pese a que Jorge Basadre puso de esto algunas líneas. Igartua dice, en cambio, que este panorama sí lo vio Bolívar, "quien no quiso un Perú fuerte e hizo del Alto Perú una nación independiente. Y, muchas páginas atrás en la historia, así también lo vio el virrey Manuel Guirior quien escribió en 1778, cuando se comenzó a hablar de la Audiencia de Charcas y de hacerla -como se hizo- dependencia del 
virreinato de Buenos Aires: "El reino del Perú, Bajo y Alto, no admite división perpetua". Y así lo entendió Portales, como señala el maestro cuando dice que... con larga y aguda visión de estadista -él es el padre de la nación chilena- advierte que es natural la unión de los dos Perúes, que el idioma -el quechua y el aimara- los unifica, que habrá con el tiempo una ligazón inseparable con Lima capital, que la Sierra y la Costa -con paridad en el diálogo- unirán capacidades y recursos. Adivina él, chileno, lo que pudo ser este país y no fue -por obra de él, en parte-, mientras que los peruanos seguimos sin captar, sin sentir el problema del indio, queriéndolo eliminar, borrando la palabra indio del diccionario. O entendiéndolo mal, soberbiamente, con desprecio, como lo entendía la frívola Lima de los años de la Confederación; la Lima que se rendía a los pies de Salaverry y Vivanco porque eran blancos, altaneros y poco sagaces; la Lima que detestó en Santa Cruz al indio. Así lo decían sus coplas", que seguramente se referían al caudillo paceño, de quien se mofa tildándolo de "Alejandro huanaco" (en alusión a Alejandro Magno y a un auquénido típico de los Andes), además de que muestra su perplejidad por haber dejado su país para emprender semejante aventura confederada:

\footnotetext{
"Que este Alejandro huanaco

extienda hasta el Juanambú

sus aspiraciones viejas.

¿Por quí, humbre, el Bolivia dejas?

¿Por quí boscas la Pirú?."
} 


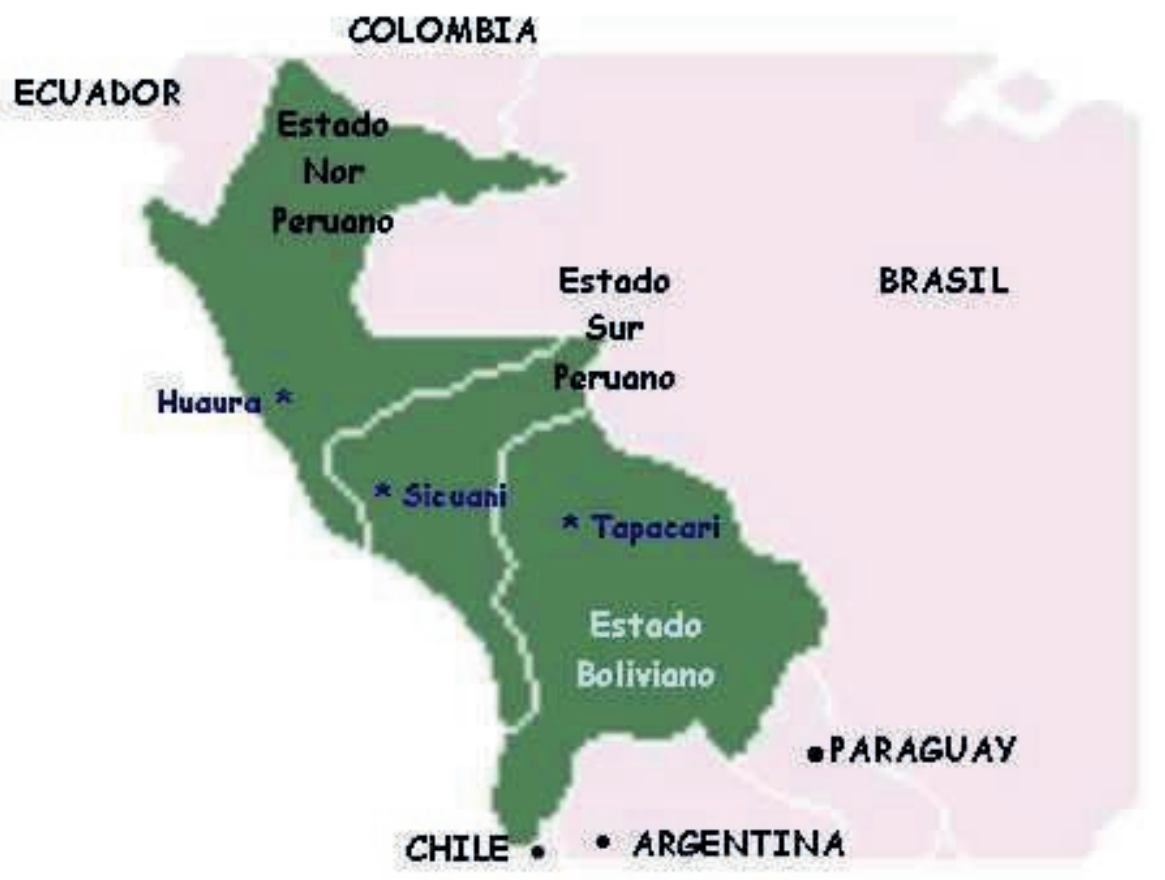

Figura 10a. Los dos perúes y una tragedia que todos (peruanos, bolivianos y chilenos) comparten pero niegan. Mapa de la Confederación Perú - boliviana, donde se puede apreciar, al norte, el territorio peruano dividido en dos estados (Nor Peruano y Sur Peruano), y al sur, el estado boliviano, también conocido como "Alto Perú". Ilustración publicada en el blog historiaperuana.blogspot.com 


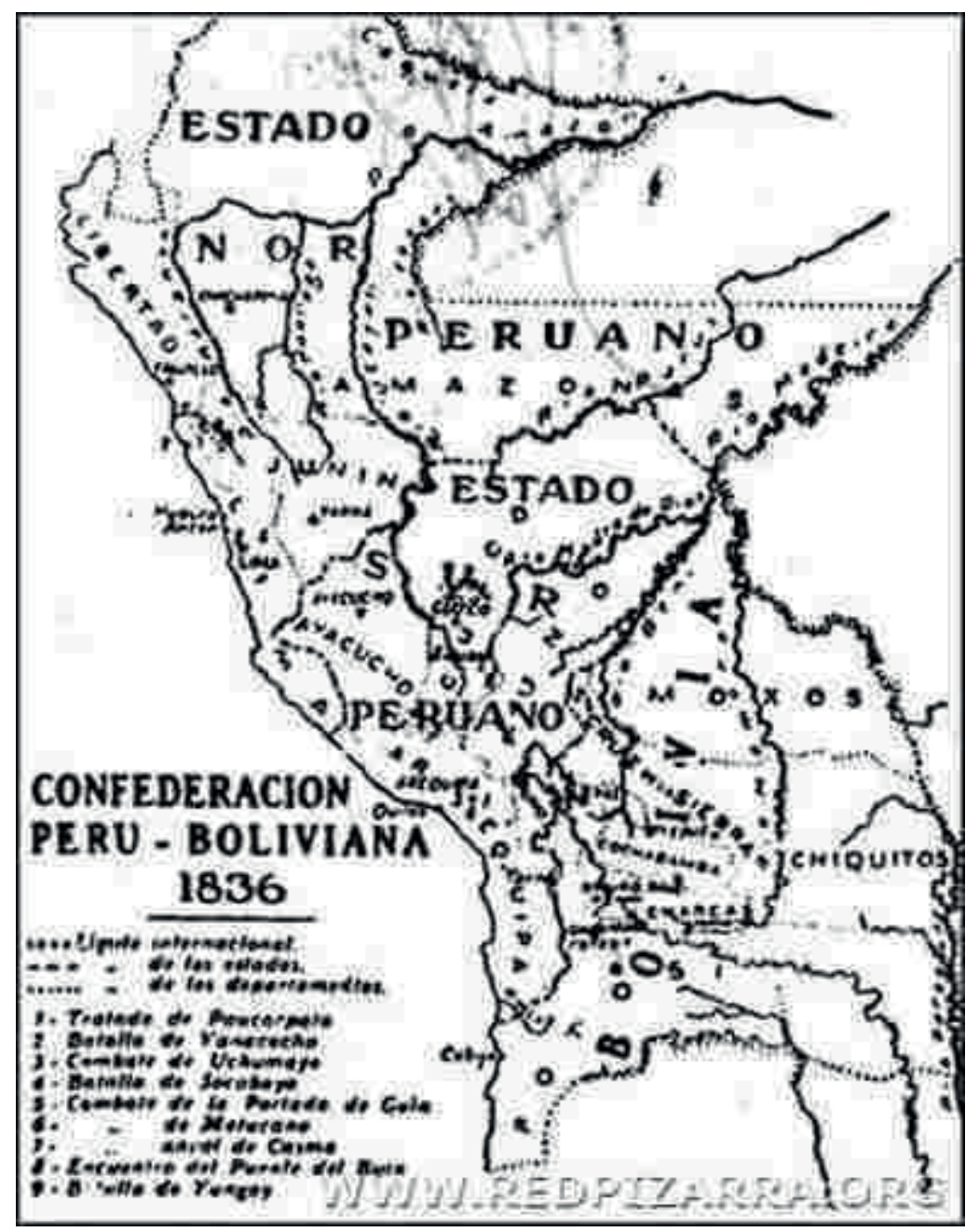

Figura 10b. Viejo mapa de la Confederación Perú-boliviana de 1836. Ilustración del sitio boliviano redpizarra.org

Entonces, a estas alturas viene una cuestión que no podemos dejar de hacer, y nos preguntamos... ¿qué hubiera pasado si Velasco, antes de acometer su asonada militar de 1968, o al premeditar el inicio de su "revolución", se hubiera detenido un momento a pensar en la historia del Perú y puesto a leer el verdadero relato de lo que acaeció entonces, con la Confederación Perú-boliviana, y se hubiera fijado en la cita premonitoria de Portales, quien, como todo buen estadista, tuvo el acierto de prever repitiendo esta frase - : "lo que pudo ser este país y no fue -por obra de él, en parte-, mientras que los peruanos seguimos sin captar, sin sentir el problema del indio, queriéndolo eliminar, borrando la palabra indio del diccionario". Si Velasco hubiera 
tenido la inteligencia de darse cuenta de esta problemática de fondo, que venía desde muy atrás, advirtiendo a los políticos de lo delicado que es tratar el tema del indio algo que, como ya se ha visto reiteradas veces, hay que tomarlo con pinzas - , tal vez se habría dado cuenta de con quiénes se estaba metiendo cuando, ya en el poder, los negó como parte ineludible de este Perú. La historia y el tiempo, pues, le dieron la razón a Portales, pues era como decir: con la raza, ni de a vainas, menos con la identidad andina. Y no han faltado quienes, olvidando tradiciones milenarias, han querido ningunear ancestrales usos y costumbres. ¡Cuántas veces se ha dicho, por ejemplo, que al indio peruano no se le puede quitar su coca!, decimos esto a modo de comparación para dar a entender que al hombre andino, de tez cobriza, no se le puede rechazar por el hecho de ser indio, menos se le puede negar su existencia o apartarlo de ese todo que es el Perú. Vale decir, no hay vuelta que darle... ¡el indio peruano tiene tanto derecho a ser "indio" como el blanco a ser "blanco" y el cholo a ser "cholo" y el negro a ser "negro" y el chino a ser "chino" y el selvático a ser "selvático"! -etnias todas que en su conjunto han configurado la peruanidad-. Entonces aquí, en el meollo del asunto, la moraleja sería que es un crimen de lesa humanidad apartar o discriminar a alguien por el color de su piel, la procedencia geográfica, el idioma o las ideas -es algo que se ha repetido hasta el cansancio en todas las lenguas, incluyendo el quechua y el aimara, y conste que esto siempre se dijo y se escribió, incluso en tantas Cartas Magnas que se redactaron durante el Perú Republicano-. Entonces, por no entender que los pueblos andinos son parte ineludible de un gran pueblo, de una comunidad enorme, de un país, al régimen de Velasco, como a la venal Lima del primer tercio del siglo XIX, se le vinieron los Apus encima... por despreciar a la raza andina representada en el caudillo boliviano Santa Cruz. Tal error, el de Velasco, como en aquellos tiempos de la Confederación donde también se despreció al indio, terminaría por pasar factura finalmente. Y la pasó de la forma más atroz un 5 de febrero de 1974, el día de la furia (Ver reportaje de Caretas, El 'Limazo', en el subcapítulo 10.4. Recortes de Prensa), cuando una huelga nacional de policías sirvió de escenografía, que sino de excusa perfecta, para el desembalse del 
pueblo de todas las sangres. Aquel aciago día, una turba descontrolada tomó por asalto las calles limeñas con una virulencia nunca antes vista. Fue la secuela de la tozudez del "chino" Velasco, quien metió las cuatro a pesar de tanto kausachum Velasco (bienvenido Velasco) -que la dictadura militar propalaba a grito pelado mediante parlantes en la Plaza Mayor de Lima y en las emisoras radiales - , siendo esta una voz decididamente quechua e indígena a pesar de su encono contra lo andino. La historia poco difundida del encuentro armado entre "peruanos chilenizados" y "peruanos-peruanos" en la batalla de Yungay marcó, pues, el corolario definitivo, el punto de quiebre que, cual hendidura en nuestra propia idiosincrasia, creció y creció, como la telúrica falla de San Andrés, en California, sumándose a las "pequeñas debacles" históricas hasta llegar a la época del régimen de Juan Velasco Alvarado y su "Gobierno Revolucionario", que completa el ciclo doloroso de nuestra historia poco conocida, subrayando el gran dilema de ¿en qué momento se jodió el Perú?. El Perú se jodió, pues, cuando su colectividad, amén de su clase política, se enteró de que el Perú no podía ser lo que pudo o debió haber sido por estas razones explicadas; se fregó cuando supo que esta derrota de Yungay fue provocada por peruanos... procedentes de Chile; el Perú se jodió, pues, cuando supo que tales peruanos "repatriados" habían ganado a los "indios" confederados de Santa Cruz, es decir, a su propia gente (Nota 14); fueron ellos, los mismísimos peruanos, quienes en ese 20 de enero de 1839 le ganaron a su propio Perú y a su caudillo circunstancial, el general Santa Cruz, que había sido rechazado por la altanera Lima por su color de piel; y se jodió también, y esta vez fue el tiro de gracia, cuando se supo que otro "indio" -pues Velasco tenía mucho de inga - , al que apodaban "chino" -tal vez por el bigotito y su voz rasposa -, entonces mandatario por la fuerza de las bayonetas, había tratado de negar la raíz andina del Perú, su propia raza. Esta es la triste conclusión a la que llega Paco Igartua tras reflexionar sobre una de las principales razones del porqué del Perú de hoy, a guisa de colofón -pues, lamentablemente hoy, como en 1995, todo sigue igual - , para que la posteridad tome nota, si es más inteligente que nuestra sociedad actual: sobre nuestras cabezas se 
levanta el cargamontón que se nos puede venir encima, otra vez, si es que alguien vuelve a meterse con ellos, como lo hicieron la frívola sociedad limeña de la primera mitad del siglo XIX y el régimen de facto del "chino" Velasco.

Nota: Este análisis debió haber visto la luz en la revista Oiga del 28 de noviembre de 2006; sí, la Oiga que nunca salió por esas "cosas" que solo ocurren en el Perú. (Nota 15)

\section{Maldición mapuche, ¿realismo o paranoia?}

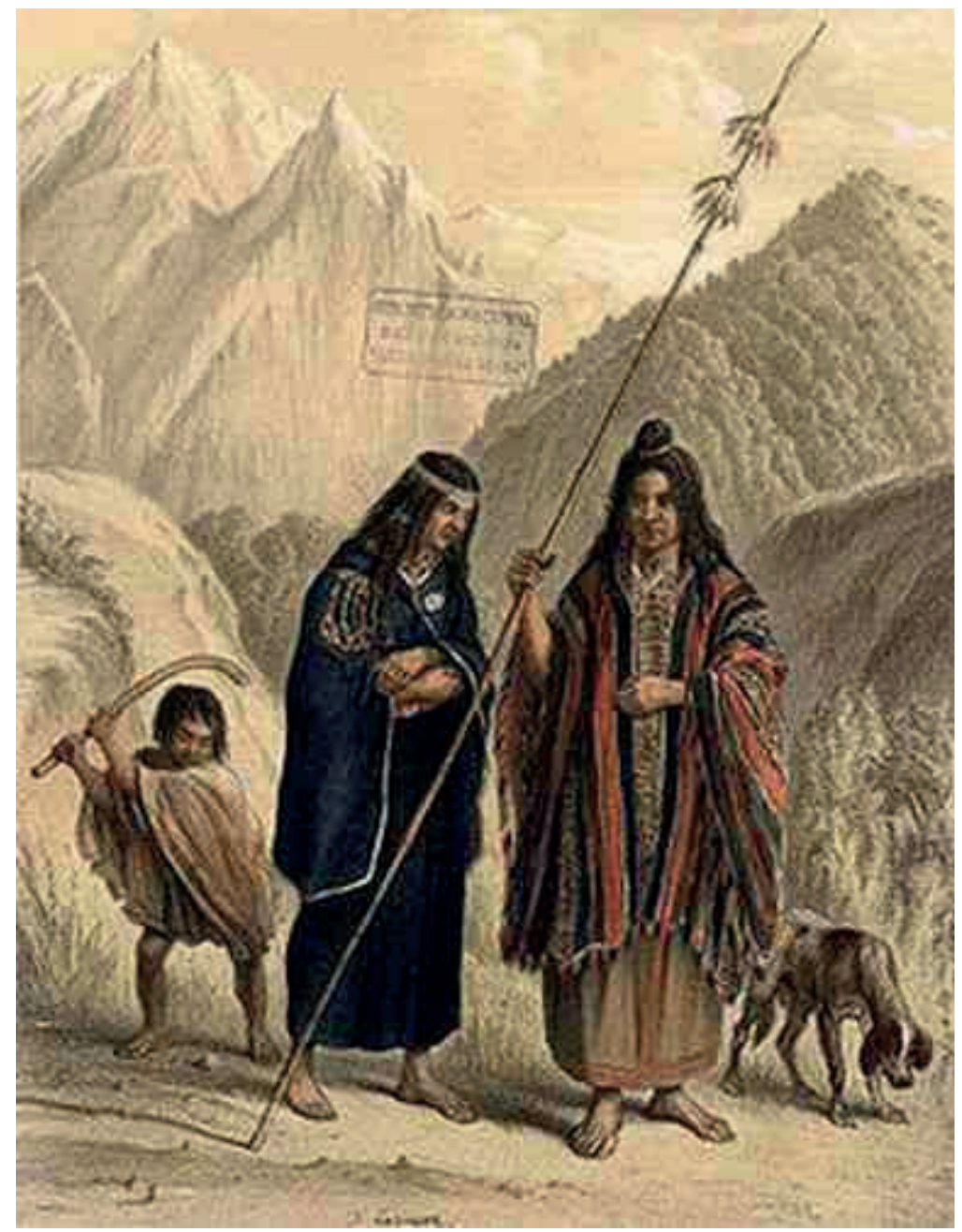

Figura 11. Mapuches chilenos del siglo XIX. Grabado de época. Ilustración de Wikipedia. 
Suena increíble, pero en Internet corre desde hace un tiempo el rumor, repetido en varios sitios Web, de que toda esta historia de la "mala leche" peruana no sería otra cosa que los efectos de una "maldición mapuche" que habría "jodido" al Perú, provocando todas sus desgracias. En Chile, que de otra forma no podía ser, hay una leyenda que así parece confirmarlo. Lo cierto es que la letra del himno nacional peruano tiene unas estrofas que habrían sido manipuladas para que brujos de esta etnia extendieran el mal agüero sobre este país cada vez que sus ciudadanos entonen esta canción emblemática. En un portal peruano, dedicado al debate político, se publicó en 2005 un artículo del periodista y humorista Luís Freire Sarría, que relata esta sorprendente historia: Maldición mapuche, ¿realismo o paranoia? El Tribunal Constitucional ha modificado la letra del Himno Nacional que estábamos acostumbrados a cantar, mandando al fondo donde siempre hay sitio, a la estrofita aquella de: "Largo tiempo el peruano oprimiiiiidooo...", en lugar de suprimirla completamente como debiera, porque esa estrofa, ¡Sí señores!, sería una maldición mapuche que no sólo sería la causa de que pierda la selección, sino de que estemos dónde estamos y tengamos los presidentes que tenemos.

Me lo reveló un individuo cuyo nombre nunca supe y me lo reveló con tal convicción, que me siento tentado a creerle. Asegura que el Perú se jodió exactamente en 1913, el año en que se oficializó la reforma del Himno Nacional. Recuerdo que me fue a buscar a mi casa (no sé cómo averiguó mi dirección) y bajando la voz hasta el susurro, me soltó la increíble verdad.

- La segunda estrofa del Himno es una maldición mapuche.

- ¿Cómo que maldición mapuche?- le pregunté, desconcertado.

- Así es, cada vez que repetimos la estrofa que incorporó José Santos Chocano...

-¿Cómo que la estrofa que incorporó José Santos Chocano?- volví a preguntar.

- José Santos Chocano ganó el concurso oficial para modificar la letra original de José de la Torre Ugarte, él es el autor de esas ocho líneas que comienzan: "Largo tiempo el peruano oprimiiiiiiido...", las únicas que cantamos después del "Somos liiiiibres..." y cada vez que las cantamos, nos apretamos un poco más la soga que llevamos puesta 
al cuello. ¿No se ha dado cuenta de que las palabras dominantes son: largo tiempo oprimido/ ominosa cadena arrastró/ condenado a una cruel servidumbre/ en silencio gimió/ indolencia de esclavo/ humillada cerviz?"

- Sí, ya lo sé, y qué- le contesté.

- ¡Esas palabras tienen poderes mágicos, no son otra cosa que un maleficio anti peruano! - exclamó, olvidándose de toda prudencia.

Logré calmarlo. Bajó la voz, pero no la intensidad de sus afirmaciones. Hace casi un siglo que nos la pasamos repitiendo: oprimido, en silencio, gimió, indolencia, arrastró, humillada y por eso, los peruanos estamos cada día más oprimidos, silenciosos, gemebundos, indolentes, arrastrados y humillados.

- ¿O sea, que Chocano jodió al Perú?- concluí, medio en broma.

- Sí, señor, Chocano versificó una maldición elaborada por brujos mapuches a sueldo del gobierno chileno para mantener hundido al Perú. Gracias a sus artes poéticas, ganó el concurso oficial e introdujo el maleficio en nuestro Himno, por eso, quiero proponer un contramaleficio, una nueva estrofa que nos saque del pozo y se la voy a cantar aquí mismo.

Se puso solemnemente de pie, con una mano en el corazón y se puso a chillar: Somos grandes y monumentaaaales/ inmensos, enormes, tremendos/ somos magnos y superlatiiiivos/y tan grandes/y tremendos/ extensos y extraordinarios/ ilimitados y desmesurados/ mayúsculos y descomunales... Si no lo saco de los sobacos, me hubiera vertido encima su nueva estrofa, mas las cinco restantes del Himno Nacional.

Cuando todo volvió a la calma, me quedé pensando: ¿Habrá nuestro poeta coronado jodido realmente al Perú? ¿Tendremos al fin la respuesta a la pregunta que formuló tan claramente Zavalita en "Conversación en La Catedral"?

Nota de Redacción: José Santos Chocano fue uno de los poetas más notables que ha tenido el Perú. Conocido como "El Cantor de América", había nacido en Lima en 1874 y representó al llamado "Movimiento Modernista" de la literatura peruana e 
hispanoamericana de inicios del siglo XX. El autor de las estrofas citadas arriba, del Himno Nacional del Perú, curiosamente, vivió exiliado en Santiago de Chile desde 1924 y murió asesinado el 13 de diciembre de 1934, tras ser apuñalado en el interior de un tranvía; por otra parte, era conocido su "chilenismo", en cierto modo a causa de su apego a los círculos literarios mapochinos, a la vez de tener muchas conexiones con políticos de ese país y peruanos, pues era diplomático. No falta quienes afirman que incluso pertenecía a una logia masónica. Durante su estadía en Santiago, fue muy conocida la oposición de Chocano hacia la entonces dictadura del presidente peruano Augusto B. Leguía (1919 - 1930), lo cual impidió su retorno a Lima. Fue el gobierno de Guillermo Billinghurst (1912 - 1914) quien convocó dicho concurso para modificar la letra del primer autor del himno peruano, José de la Torre Ugarte.

Fuente: Terra Noticias - "Palabra de Loco" (Nota 16)

\section{Para saber más...}

(Anotación: A la derecha de los hipervínculos se ha insertado la fecha de última apertura de la página Web citada)

Bolivia y Perú: la fraternidad escindida.

http://www.geocities.com/novembrino2002/a001118_07_01.htm (10/3/09)

Historia del himno de Yungay que canta Chile.

http:/ / amautacuna.blogspot.com/2007/04/

el-himno-de-yungay-que-canta-chile.html (10/3/09)

La Independencia del Perú y la conciencia turbia.

http://amautacuna.blogspot.com/

2007/07/la-independencia-del-per-y-la.html (10/3/09) 
La batalla de Yungay (Wikipedia)

http:/ / es.wikipedia.org/wiki/Batalla_de_Yungay (5/3/09)

Capítulo 15: La guerra contra la Confederación peruano-boliviana. El papel chileno en la misma.

http:/ / www.cema.edu.ar/ceieg/arg-rree/3/3-042.htmy y sitios web ss. (9/3/09)

Yungay ¿fiesta o velatorio? http:/ / www.voltairenet.org/article143781.html (9/9/09)

Juan Velasco Alvarado (Wikipedia)

http:// es.wikipedia.org/wiki/Juan_Velasco_Alvarado (3/3/09)

Revolución de las Fuerzas Armadas (página discrepante en Wikipedia) http://es.wikipedia.org/wiki/

Revoluci\%C3\%B3n_de_las_Fuerzas_Armadas (10/3/09)

Incas sí, indios no: Apuntes para el estudio del nacionalismo criollo en el Perú http:/ / www.cholonautas.edu.pe/modulo/upload/Mendez.pdf (10/3/09)

El gobierno de Juan Velasco Alvarado: Estudio de un caso histórico de cesarismo. http:/ / mujer.indomable.peru.googlepages.com/velazcoavarado.pdf (10/3/09)

Guerra entre Salaverry y Santa Cruz.

http:/ / es.wikipedia.org/wiki/Guerra_entre_Salaverry_y_Santa_Cruz (10/3/09)

Historia de Bolivia de Pedro Dávalos y Lisson - La primera centuria: causas geográficas, políticas y económicas que han detenido el progreso moral y material del Perú en el primer siglo de su vida independiente. Tomo III - Caps. V, VI, VII, VIII y IX 
http://www.cervantesvirtual.com/servlet/

SirveObras/01316119700682055644802/p0000003.htm y ss. (10/3/09)

Himno Nacional del Perú - Historia (Wikipedia)

http://es.wikipedia.org/wiki/Himno_Nacional_del_Per\%25C3\%25BA (1/3/09)

Municipalidad Provincial de Yungay. http://www.muniyungay.gob.pe/ (2/3/09)

Los mapuches.

http:/ / es.wikipedia.org/wiki/ Araucano (11/3/09)

\section{Epílogo: un poco de optimismo no hace daño (hay quienes piensan diferente...)}

\subsection{Los andinos tenemos una mirada abarcadora}

Artículo de Gonzalo Pajares Cruzado, publicado en Peru 21, Lima 21/02/07 Reedición PortaLibros.com (Nota 17)

El cusqueño Luis Nieto Degregori mezcla la historia con la literatura. Asesinato en la Gran Ciudad del Cuzco (Norma), su última novela, es resultado de este ejercicio. El libro sale a la venta hoy y nos revela a un autor que, como él mismo dice, "hurga en el pasado para hablar del presente".

¿Siempre le ha interesado la historia?

Siempre. Me interesa la historia como una manera de entender el Perú actual. Por ello, prefiero sus pasajes conflictivos. En Asesinato en la Gran Ciudad del Cuzco parto de una anécdota policial para indagar en los conflictos del Perú del siglo XVIII: la lucha entre criollos cusqueños con españoles y el surgimiento de una conciencia mestiza en la sociedad cusqueña. Sin embargo, este conflicto es distinto al de Túpac 
Amaru, pues el levantamiento de este curaca es una expresión de la rebeldía indígena.

¿Qué tantas licencias se toma para novelar un hecho real?

Bueno, parto de una investigación rigurosa. Estuve trabajando, gracias a una beca del Gobierno español, varios meses en el Archivo de Indias de Sevilla. Hecha la pesquisa, ficciono estos episodios históricos y me tomo muchísimas libertades. Novelo la realidad para dar luces sobre ella.

¿Por qué su interés en hurgar el pasado para explicar el presente?

Bueno, mis historias abarcan varias épocas. Por ejemplo, ahora escribo una novela sobre Lima que tiene como fondo el tema Guachimán, de La Sarita. Soy de los escritores que consideran que el problema más serio de la sociedad peruana es la discriminación de sectores muy importantes: los indígenas, los mestizos. Esto impide que nuestro país avance.

Como cusqueño, ¿siente que su mirada es distinta a la de un escritor limeño?

Esto me hace recordar la polémica entre autores andinos y criollos. Muchos escritores provincianos tenemos la ventaja de sentir en carne propia la marginación, algo que desde Lima no se ve. La sociedad criolla no tiene la capacidad de ver los conflictos del Perú actual; la provinciana, sí. Un provinciano nace sabiendo que hay varios Perú y que muchos de ellos están enfrentados. Es decir, hay una visión criolla, otra andina y otra india del Perú. Escritores como yo ofrecemos la mirada andina.

¿Y esta es más certera?

Es distinta. Yo diría que es abarcadora. La visión criolla deja de lado aspectos muy importantes de nuestra sociedad. Siempre hago referencia a la frase de Vargas Llosa: "¿En qué momento se jodió el Perú?". Lo que se jodió fue el Perú criollo, porque el Perú está mejorando. Cuando uno conversa con un poblador pobre de la sierra, nos 
dice que, con referencia a su padre, su vida es mucho mejor porque ya no es siervo, porque el gamonal ya no puede violar a su mujer o a su hija. Y no estoy hablando de hace un siglo, sino de hace 20 o 30 años.

\section{¿Cómo es esta mirada criolla?}

Una de sus limitaciones es que deja de lado a vastos espacios de nuestra sociedad y de nuestra cultura. El debate entre los escritores ayudó a visibilizar a los escritores andinos. Porque lo que hace falta en nuestro país es visibilizar -pongo énfasis en esto- estos sectores marginados que, además, son grandes creadores de cultura. La capacidad de dar una visión más amplia del Perú es lo que nos diferencia a los provincianos. El Perú andino es emergente; el criollo, decadente. El Perú andino ha conquistado Lima, y ahora lucha por que no haya marginación y discriminación.

Si la frase de Vargas Llosa no es certera, ¿cuál utilizaría usted?

"¿Cuándo arreglaremos el Perú?". Porque lo estamos arreglando.

\section{Notas al Margen y Referencias}

(Anotación: A la derecha de los hipervínculos se ha insertado la fecha de última apertura de la página Web citada)

Nota 1. Seix Barral, Nueva Narrativa Hispánica, 1980

Nota 2. Apostando por la derrota, para variar. Desde Lima me llega una carta de un amigo entrañable, criticando mi columna del domingo pasado. "Tu artículo me jodió" -me dice sin eufemismo alguno. Y creo que da en el clavo. Algo de eso perseguía, sospecho, al escribirlo. Ese autismo colectivo que, en mi opinión, padecemos los peruanos, y que nos lleva tanto a la desidia como al cinismo, tiene muchas explicaciones. Para no abusar de la paciencia del lector, podríamos remitirnos tan 
solo a las dos últimas décadas de nuestra historia para encontrar algunas respuestas. A diferencia de lo que ocurría hasta los años 80, ahora hemos quedado huérfanos. De padres y de arquetipos, cierto, pero también de ideas. Intelectualmente hablando, al menos, esos años marcaron el fin de las utopías y de los grandes paradigmas. Después vino la diáspora. Y nos quedamos en el individualismo más paupérrimo y menos creativo. De ahí nuestra desidia cotidiana, nuestro mediocre conformismo. Acaso ello explique la escasez de imaginación y el exceso de cinismo de nuestras elites.

Observemos, sino, los resultados de la última encuesta de Datum. A nivel nacional, si las elecciones fueran mañana, Alan García obtendría 23\% y Alberto Fujimori 19\%. Increíble, pero cierto. Dos de los políticos peruanos que son, para muchos, sinónimos de corrupción y autoritarismo, entrarían a la segunda vuelta. Demás está agregar que es indispensable vivir en el Perú para encontrar cierta lógica a dicho absurdo. O intentarlo, al menos. Porque desde fuera, nadie con dos dedos de frente puede entender ese escenario. Esta perversa proclividad nuestra a coquetear con el mal y apostar por la derrota parece ser, desgraciadamente, endémica. Hugo Neira decía ayer, en su última sabatina, que para vencer un mal los peruanos solemos caer en otro. $\mathrm{Y}$ en otro y en otro y en otro, ad infinitum -agrego yo-, convencido en que Hugo, ese optimista ejemplar y casi especie en extinción, entenderá mi peculiar forma de coincidir con él. ¿No es ello, acaso, producto de nuestra proclividad por la inmoralidad como doctrina, por la componenda como un consenso mal entendido? ¿No es ello también parte de esa cultura autoritaria y sumisa, que nos lleva a seguir buscando líderes providenciales que nos alimenten de ilusiones? Pensémoslo.

A la distancia, por ejemplo, observo el comportamiento de Alan García en el último congreso del Apra. El principal líder de la oposición peruana (según el 60.3 \% de la población) tuvo que recurrir a las viejas maniobras autoritarias para imponer su propia voluntad, por encima de la voluntad de la mayoría de delegados. Se obvió el 
debate interno y se optó por la componenda. Se apostó por las viejas maniobras patronales y no por la esperada renovación de la que tanta gala ha venido haciendo el mismo García. De no haber sido por ese poco democrático afán suyo, Jorge del Castillo hubiera ganado limpiamente las elecciones. ¿Y qué? ¿No era esa la voluntad de las mayorías? Es más, incluso entendiendo la imagen concertadora que quería proyectar García, si el asunto se hubiera resuelto democráticamente, no hubiera sido Mauricio Mulder sino Carlos Roca el acompañante de Del Castillo en la dupla de Secretarios Generales. ¿Es eso un ejemplo de democracia? Lo dudo. Al parecer, a García le importa más imponer temor que respeto. Entonces, ¿cómo espera que los peruanos no apristas $\mathrm{y}$, especialmente, la comunidad internacional, crea en sus supuestas buenas y dizque modernas intenciones? Difícil. Me temo que Alan sigue apostando por el camino fácil. Y ese es llegar al poder aprovechando las debilidades de una sociedad, en lugar de educándola. Porque el nuestro es un terreno fértil para el pícaro, para el sinverguenza, para el vivo. Más que el valor o el entusiasmo, lo que nos define es la pendejada. Y eso lo saben demasiado bien nuestros políticos. Por eso nos usan. ¿Lo sabemos nosotros? Artículo publicado en el diario Perú 21, Lima, 20 de junio de 2004.

http://peru21.pe/impresa/noticia/

apostando-derrota-variar/2004-06-20/6227 (4/3/09)

Nota 3. La derrota no parece inmutarnos, esta es la conclusión a la que llega el periodista peruano Carlos Paucar, cuando escribe: Derrotas ante El Salvador y Paraguay y nadie dice nada, nadie se despeina, nadie se indigna. Nos hemos acostumbrado a perder, a que la palabra triunfo suene tan extranjera. ¿Qué pasa con el fútbol que se ha convertido en el despensero de conformistas, de apáticos, de desilusionados, en suma, de perdedores?

Es cierto que nunca fuimos los mejores, que la alegría pertenecía a brasileños y argentinos. Pero tampoco éramos los últimos de la fila. Hasta los años 70 el fútbol 
peruano era reconocido y a inicios de los 80 los extranjeros debían sufrir aquí para llevarse un empate. Pero después todo se vino abajo: el caos de los clubes, la sinvergüencería de los dirigentes, la falta de dignidad de los entrenadores a quienes las derrotas no los mueven de sus cargos y el escaso profesionalismo de los jugadores.

Entonces los intelectuales metieron su discurso al fútbol y machacaron: nunca fuimos nada, lo de Berlín era un bluf, el título en el Sudamericano del 39 fue contra nadie, la Argentina eliminada el 69 venía mal, en México 70 sólo le ganamos a Bulgaria y a Marruecos, en el 78 Escocia estaba en cero y Holanda se dejó empatar, y en el 81 se eliminó a un pésimo Uruguay, etc. Lo peor es que este discurso sirvió de argumento para entrenadores perdedores, dirigentes incapaces, y periodistas que siguen acomodados en medio de esta ola de fracasos. Aceptar esta cultura de la derrota nos convertirá en sus cómplices. Y eso no puede ser. Artículo: "La cultura de la derrota", publicado en el diario La República, Lima, 18 de febrero de 2009. http:// www.larepublica.pe/cosas-de-la-tribu-carlos-paucar /18/02/2009/la-cultura-de-la-derrota (2/3/09)

Nota 4. Esta es la versión revisada de una conferencia presentada en el "Primer encuentro de historiadores peruano-ecuatorianos" que tuvo lugar en Lima el 19 de noviembre de 1999 en la Pontificia Universidad Católica del Perú. Un primer esbozo de este texto fue discutido en SUR. Casa de Estudios del Socialismo, el 18 de setiembre de 1998.Texto de Cecilia Méndez G. http://www.cholonautas.edu.pe/ / Biblioteca Virtual de Ciencias Sociales. (5/3/09)

Nota 5. Algunos investigadores han llamado la atención sobre esta dificultad de los peruanos para lidiar con su pasado. Por ejemplo, Carmen Mc Evoy llama la atención sobre el carácter "algo desmemoriado" de los peruanos, señalando cómo los discursos políticos se han sucedido unos a otros sin reconocer sus raíces en los que los 
precedieron, presentándose a menudo como "fundadores": La utopía republicana ideales y realidades en la formación de la cultura política peruana (1871-1919). Lima: Pontificia Universidad Católica del Perú, 1997. Por su parte. Gonzalo Portocarrero se ha referido a la dificultad de los peruanos para elaborar una "memoria colectiva", razón que lo lleva a escribir Razones de sangre: aproximaciones a la violencia política. Lima: Pontificia Universidad Católica del Perú, 1998, pp. 9-13. Texto de Cecilia Méndez G. http:/ / www.cholonautas.edu.pe/ / Biblioteca Virtual de Ciencias Sociales. $(5 / 3 / 09)$

Nota 6. Pongo este ejemplo porque esta pregunta ha sido un motivo recurrente en la reflexión sobre el país, como lo demuestra la publicación, en la década de 1980, de un número de la revista Hueso Húmero dedicado a este tema, y un volumen editado posteriormente por Carlos Milla Batres, ¿En qué momento se jodió el Perú? Lima: Milla Batres, 1990. Texto de Cecilia Méndez G. http://www.cholonautas.edu.pe/ Biblioteca Virtual de Ciencias Sociales.

Nota 7. La Ventana Indiscreta, "Cuando se jodió el Perú", 28 de julio de 2008. http://www.agenciaperu.tv/ventana/?q=node/381 (5/3/09)

Nota 8. El Partido Civilista o Partido Civil fue un partido conservador en Perú durante la segunda mitad del siglo XIX y la primera del siglo XX. Esta agrupación fue fundada como una medida opositora al creciente poder que iban teniendo los militares durante la historia de la República, el único objetivo del partido fue establecer un gobierno civil en el país. Su fundador fue don Manuel Pardo y Lavalle, el primer presidente civil del Perú (1872 - 1876).

Nota 9. Pierolistas, nombre que recibían los seguidores del llamado Partido demócrata, fundado por don Nicolás Fernández de Piérola Villena (n. 1839 - m. 1913). Piérola Fue un político peruano a quien sus simpatizantes apodaban "el califa". 
Ocupó la presidencia del Perú en dos ocasiones (1879 - 1881 y 1885 - 1899). En más de una ocasión intentó deponer a los gobiernos de Manuel Pardo y Mariano Ignacio Prado (1874 - 1877), pero tuvo que exiliarse en Bolivia y Chile. Cuando estalló la guerra con el vecino sureño (1879) aprovechó la ausencia de Mariano Ignacio Prado para dar un golpe de estado y hacerse con el poder, en calidad de Jefe Supremo, cargo que mantuvo hasta que las tropas chilenas ocuparon Lima enero de 1881. Luego estableció su gobierno en la sierra peruana. En noviembre de ese mismo año presentó su renuncia a la presidencia de la República y en 1882, en plena Guerra del Pacífico, fundó el Partido Demócrata. Tres años después (1885), se alió con el Partido Civil y organizó guerrilleras con las que llegó a ocupar la ciudad de Lima, provocando la renuncia del entonces presidente Andrés Avelino Cáceres, luego de lo cual fue elegido Presidente de la República. Durante su segundo mandato realizó importantes reformas económicas. Falleció en Lima el 23 de junio de 1913. Según algunos autores, Piérola fue el artífice de la Reconstrucción nacional y el iniciador de la llamada República aristocrática.

Nota 10. ¿En qué momento se jodió el Perú? Publicado en el portal Amautacuna http:/ / amautacuna.blogspot.com/2007/07/en-qu-momento-se-jodi-el-per.html $(8 / 3 / 09)$

Nota 11. Op. Cit. Empresa Editora Lima, febrero 1977

Nota 12. Por una cruel ironía de la historia, fue el propio presidente Agustín Gamarra quien premió a los vencedores de Yungay, tal como relata el historiador chileno Ricardo Aguilar Cubillos, cuando hace un análisis de la llamada "Guerra contra la Confederación Perú - boliviana": El 21 de agosto de 1838 tuvo lugar el Combate de Portada de Guías, que permitió la ocupación de Lima por el ejército chileno, comandado por Bulnes. En la capital peruana se convocó un cabildo abierto que proclamó como presidente provisional del Perú al general Gamarra. A este 
primer éxito bélico chileno le sucedieron en enero de 1839 el Combate Naval de Casma, en donde los corsarios franceses que luchaban al lado de la Confederación fueron derrotados por Robert Simpson. Posteriormente el ejército de Santa Cruz fue completamente derrotado en la Batalla de Yungay, el 20 de enero de 1839. En esta batalla las tropas de la Confederación esperaban resistir la ofensiva de Bulnes parapetadas en el cerro Pan de Azúcar. Tras el combate, el general chileno Manuel Bulnes fue nombrado Gran Mariscal de Ancash por el general peruano Agustín Gamarra.

Texto extraído del portal "Historia y Ciencias Sociales", Conflictos I http:/ / raguilarcubillos.galeon.com/aficiones1380059.html (5/3/09)

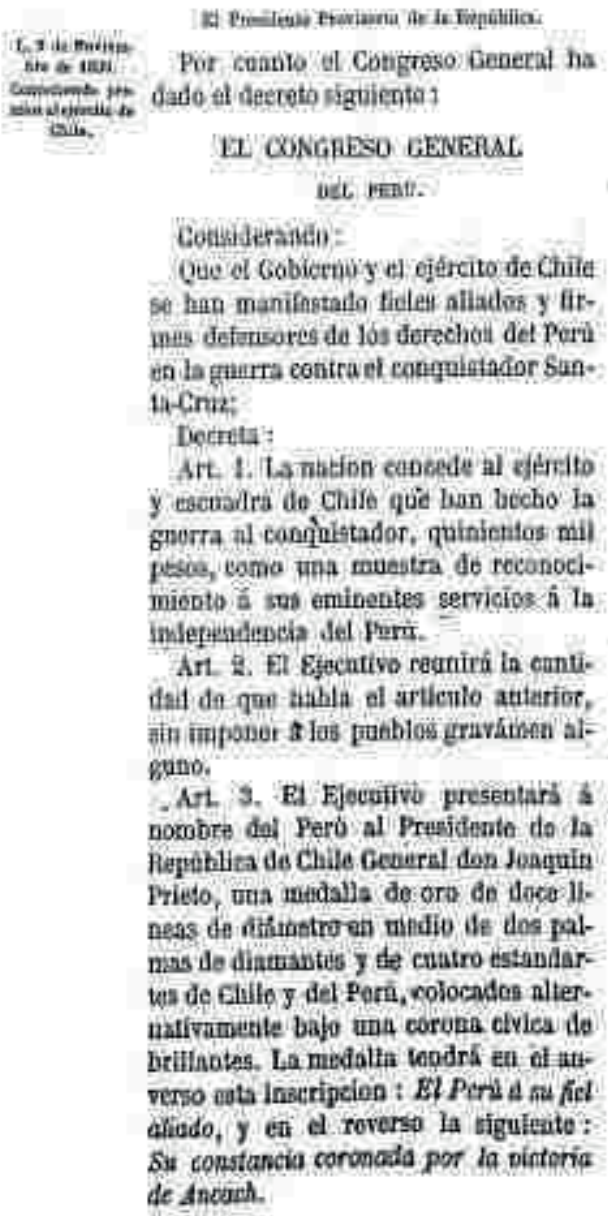

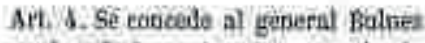

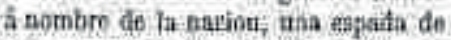
on guamecida de brillant"s, con his armiti de anbus Thegubitean brabulus

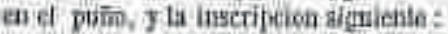

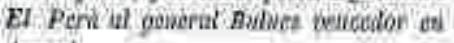
Aronat.

Comatiquese al Poder Elentivo para que dieponza 10 otcomatio is su cuínpl-

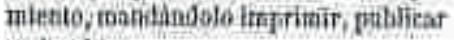
y cincular.

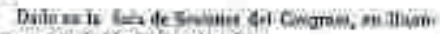

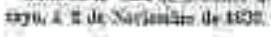

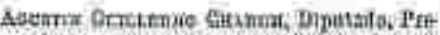

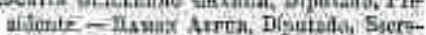

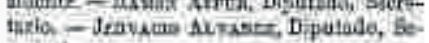
eweistis.

El Ministro de Eatudo, th d derpasho de la Guerta queda encargado de st complimientb.

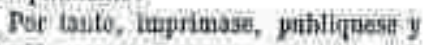
circúles:

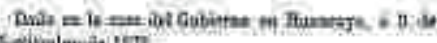
Reribalmata isp

Anumin Garamin.

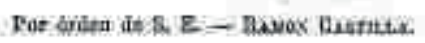


Figura 12. Decreto del presidente Gamarra, dado en Lima el 2 de noviembre de 1839, que agradece los servicios prestados y concede premios a los jefes y militares chilenos que participaron en la Batalla de Yungay, entre estos una espada de oro, guarnecida de brillantes, con las armas de ambas repúblicas grabadas en el puño, y la inscripción siguiente: El Perú al general Bulnes vencedor en Ancash. El referido militar chileno, además, fue nombrado Gran Mariscal de Ancash, por haber derrotado, al mando del Ejército Unido Restaurador, al Ejército Confederado del general Andrés de Santa Cruz. Documento conservado en el Archivo del Congreso de la República del Perú.

Nota 13. ¿Quiénes eran estos exiliados peruanos que pelearon contra Santa Cruz en Yungay? Una versión refiere que en Yungay el Ejército Unido Restaurador del general Manuel Bulnes disponía de unos 5,267 hombres, entre los que se contaban 800 peruanos (hay quienes hablan de 4,500 chilenos y 1,000 peruanos), todos procedentes de Chile y Ecuador -entre ellos Gamarra y Castilla - , adonde se habían refugiado debido a la crueldad del general Santa Cruz, quien había hecho fusilar a varios opositores, entre ellos a Felipe Santiago Salaverry, un antiguo aliado suyo (ver en 6. Para Saber Más, artículo de la Wikipedia: Guerra entre Salaverry y Santa Cruz) Se trataba de peruanos contrarios a Santa Cruz que después se pasaron al bando de Bulnes y Gamarra para marchar contra la Confederación Perú - boliviana que lideraba Santa Cruz. Otra fuente señala, por su lado, que al momento de la batalla de Yungay este ejército -el de la segunda Expedición Restauradora al Perú - contaba con unos 5.400 hombres, entre los que había numerosos jefes peruanos, pero la tropa de esa nacionalidad estaba conformada por solo 60 soldados. Por su parte, hay quienes indican que el Ejército Confederado de Santa Cruz había reunido a 5,500 hombres (6,500 según otros). A resumidas cuentas, se trató de un enfrentamiento entre las tropas confederadas de Santa Cruz, conformado por soldados peruanos (procedentes de los estados Nor-Peruano y Sud-Peruano) y bolivianos, y el Ejército de Chile, conformado por soldados de ese país, liderados por Bulnes, y tropas 
separatistas del Perú contrarios a la Confederación, es decir, el llamado "Ejército Restaurador del Perú", cuyo jefe era el presidente peruano Agustín Gamarra. Se trató, pues, de una batalla entre compatriotas (ver nota siguiente, 14), como dio a entender Francisco Igartua.

Nota 14. Aguilar Cubillos, al describir, en un apretado resumen, el derrotero que siguió la guerra de Chile contra la Confederación Perú - boliviana, desde 1836 hasta 1839, no puede dejar de ensombrecerse por el final que tuvo esta contienda, que acabó, como bien alude Igartua, enfrentando absurdamente a peruanos contra peruanos, muchos de los cuales dejaron la piel y la sangre en el campo de Yungay, vanamente: Las explicaciones principales de este conflicto son: La rivalidad comercial entre Chile y Perú. El no pago a Chile de un empréstito hecho a Perú, en tiempos de la Independencia. El amparo clandestino por parte de Andrés de Santa Cruz a dos barcos comandados por Ramón Freire, que se dirigieron a Chile para derrocar al gobierno de Prieto y Portales. Este intento fracasó y Portales ordenó dar un golpe a la escuadra de la Confederación, cuyos barcos cayeron en poder de Chile. El encargado de preparar una expedición hacia Perú para disolver a la Confederación fue Manuel Blanco Encalada. Portales se dirigió a Quillota para inspeccionar los preparativos, pero -en el camino- fue tomado prisionero por oficiales descontentos con su política y llevado a Valparaíso. Blanco Encalada detuvo a las fuerzas amotinadas y logró desbandarlas. En medio de la confusión, el ministro Portales fue fusilado. Este suceso conmovió al país. Además, Blanco Encalada fracasó en su expedición y firmó el Tratado de Paucarpata, que reconoció a la Confederación y comprometió a Chile a devolver los barcos capturados. En septiembre de 1837 el gobierno de Chile estaba resuelto a acabar con la contienda. Para ello envió una escuadra al mando de Blanco Encalada y Roberto Simpson, la cual ocupó Arequipa (Perú), si bien no encontró la ayuda y adhesión que supuestamente le habían manifestado las noticias de ciertos agentes peruanos. Al verse en franca minoría, Blanco Encalada no tuvo más remedio que firmar un tratado de paz, el Tratado de 
Paucarpata, que establecía la devolución a Perú de los barcos apresados, el reestablecimiento de las relaciones comerciales, la retirada del ejército chileno, así como el reconocimiento peruano de la deuda reclamada. En diciembre, cuando Blanco Encalada llegó a Valparaíso, los términos del acuerdo no sólo no convencieron sino que enojaron al gobierno chileno y a la opinión pública en Chile. Tanto Blanco Encalada como Antonio José de Irisarri fueron acusados y juzgados como responsables de esta afrenta, aunque finalmente fueron absueltos. El gobierno chileno desaprobó el tratado y ordenó una segunda expedición más numerosa, bajo las órdenes del general Manuel Bulnes. En 1838, el general chileno Manuel Bulnes Prieto, al mando de un ejército de seis mil hombres, emprendió la contienda. La singularidad en esta ocasión, además del notable incremento de tropas disponibles, era la presencia del general peruano Agustín Gamarra y otros exiliados peruanos en las filas de la expedición, lo cual le confería el carácter de contienda civil peruana. Texto extraído del portal "Historia y Ciencias Sociales", Conflictos I

http://raguilarcubillos.galeon.com/aficiones1380059.html (7/3/09)

Nota 15. Art. Cit. V Etapa, ¿\# 577...? (QEPD... 28/11/2006)

Nota 16.http://www.terra.com.pe/noticias/columnista/22/22526.html (5/3/09)

Nota 17. Los andinos tenemos una mirada integradora. http://www.librosperuanos.com/autores/nieto-degregori2.html (5/3/09)

Nota 18. Después de que se jodió el Perú. Diario El País. http:// www.jorgeeduardobenavides.com/ prensa/pdf/20020315.htm (5/3/09)

Nota 19. V Etapa, \# 576, pp. 13 - 21 
Nota 20. Editorial Libre, Segunda Edición, Lima, 1992, pp. 221 - 224

$\begin{array}{lllll}\text { Nota } & \text { 21. } & \text { Revista } & \text { Caretas. } & \text { Edición }\end{array}$ http:/ / www.caretas.com.pe/2000/1604/articulos/limazo.phtml 10/3/09

\section{Origen de las ilustraciones}

(Anotación: A la derecha de los hipervínculos se ha insertado la fecha de última apertura de la página Web citada)

Figura 1a. Caricatura de Molina en El Comercio.

http:/ / www.elcomercio.com.pe/impresa/

edicion/2009-03-04/ ecop040309a4 (9/3/09)

Figura 1b. http:/ / www.geocities.com/awcampos/cart.html (9/3/09)

Figura 1c. http:/ / blog.natudel.com/?p=30 (Enlace roto $-21 / 10 / 2008)$

Figura 2. Portada del libro Conversación en la Catedral, edición Seix Barral, 1980 http:/ / www.geocities.com/awcampos/vlibros.html (9/3/09)

Figura 3a. Mapa de la batalla de Yungay.

http:/ / es.wikipedia.org/wiki/Batalla_de_Yungay (9/3/09)

Figura 3b. Sello chileno de la batalla de Yungay.

http:/ / www.chilecollector.com/archwebfila03/

archwebstamp1300/stampset1331_34.html (9/3/09) 
Figura 4. El General Andrés de Santa Cruz.

http://www.umss.edu.bo/Enlaces/Ecem/historia.html (9/3/09)

Figura 5. El golpe de Juan Velasco Alvarado.

http:// pospost.blogspot.com/2008/10/

el-golpe-juan-velasco-alvarado-40-aos.html (9/3/09)

Figura 6. Campesinos de Anta (Cusco) después de la Ley de Reforma Agraria de Velasco

(1969).

http:// www.cnr.org.pe/galeria/ displayimage.php?album=10\&pos=1 (9/3/09)

Figura 7. El Gran Mariscal Ramón Castilla.

http:/ / es.wikipedia.org/wiki/ Archivo:RamonCastilla.jpg (9/3/09)

Figura 8. Agustín Gamarra.

http://es.wikipedia.org/wiki/Agust\%25C3\%25ADn_Gamarra (9/3/09)

Figura 9. Diego Portales.

http:/ / alejandro-historiaygeografia.blogspot.com/

2007/12/diego-portales.html (9/3/09)

Figura 10a. Los dos perúes.

http:/ / historiaperuana.blogspot.com/2005/

10/chile-contra-la-confederacin-per.html (9/3/09)

Figura 10b. Mapa de la Confederación Perú - Boliviana de 1836.

http://www.redpizarra.org/HuellasDeBolivia/

MapaDeLaConfederaci\%F3nPer\%FA-Boliviana (4/3/09) 
Figura 11. Mapuches del siglo XIX. http:/ / es.wikipedia.org/wiki/Araucano $(9 / 3 / 09)$

Figura 12. Decreto del presidente Gamarra, que concede premios... http:/ / www.congreso.gob.pe/ntley/Imagenes/LeyesXIX/1839085.pdf (9/3/09)

Figura 13a.

http:/ / www.caretas.com.pe/2000/1604/articulos/limazo.phtml (10/3/09)

Figura 13b.

http:/ / www.caretas.com.pe/2000/1604/articulos/limazo.phtml (10/3/09)

Figura 13c.

http:/ / www.caretas.com.pe/2000/1604/articulos/limazo.phtml (10/3/09)

Figura 13d.

http://www.caretas.com.pe/2000/1604/articulos/limazo.phtml (10/3/09)

Figura 13e.

http:/ / www.caretas.com.pe/2000/1604/articulos/limazo.phtml (10/3/09)

Figura $13 f$.

http:/ / www.caretas.com.pe/2000/1604/articulos/limazo.phtml (10/3/09)

Figura 13g.

http:/ / www.caretas.com.pe/2000/1604/articulos/limazo.phtml (10/3/09)

Figura 13h.

http:/ / www.caretas.com.pe/2000/1604/articulos/limazo.phtml (10/3/09) 
Figura 13k.

http:/ / www.caretas.com.pe/2000/1604/articulos/limazo.phtml (10/3/09)

\section{Recortes de Prensa}

\subsection{Después de que se jodió el Perú}

Artículo de Ignacio Echevarría, publicado en el suplemento Babelia, diario El País (Madrid) 16/03/2002 (Nota 18)

La historia de un pueblo seducido una y otra vez por el 'populismo medieval' y sus consecuencias, corrupción y miseria, es el tema de una de las novedades más destacadas de la temporada en cuanto a primeras novelas se refiere. Los años inútiles, de Jorge Eduardo Benavides, ofrece un retrato de la sociedad y la política peruanas del Gobierno aprista. Completan este panorama de primeras novelas cuatro libros premiados por instituciones públicas que contribuyen así a ampliar el tejido literario, distinto al comercial, con autores como Jesús de las Heras, Sonia Mollá, José María Royo y Rafael Acevedo.

¿En qué momento se jodió el Perú? La pregunta que Zavalita, el personaje de Conversación en La Catedral (1969), de Mario Vargas Llosa, no deja de repetirse, parece resonar impertérrita, más de tres décadas después, en la primera novela de Jorge Eduardo Benavides (Arequipa, 1964), cuyos personajes, lo mismo que Zavalita, también acaban preguntándose ellos mismos en qué momento se jodieron sus propias vidas.

Los 'años inútiles' a los que alude el título podrían serlo precisamente por eso: porque en ellos nada se dio por aprendido, y el país entero, en el periodo del Gobierno aprista, de cuyo despegue y estertores se da aquí cuenta, siguió jodiéndose igual que lo había hecho en el pasado, y como seguiría haciéndolo en el futuro. 
'En el Perú, la esperanza sólo es algo que perdemos violenta y cruelmente todos los días', llega a decirse por algún lado. Y se dice después de consignar la 'ciega credulidad' de un pueblo que se dejó seducir por lo que Benavides califica de 'populismo medieval', sin que el saldo de corrupción y de miseria que se derivó del mismo impidiera que el mismo pueblo, inmediatamente después, se dejara seducir por un nuevo populismo, esta vez el de Fujimori.

Un tejido hábilmente trenzado de vidas cruzadas sirve a Benavides para ofrecer no tanto una indagación de las razones por las que, una vez más, se jodió el Perú, como del modo en que, al ocurrir eso, fue estragada la vida de una nueva generación de peruanos, víctimas, una vez más, de su país, vale decir de sí mismos. En este sentido, la novela es impecable: es sobre todo el deterioro progresivo de su situación material el que determina la creciente confusión moral de sus principales personajes, generando las dos cosas sumadas la deprimente convicción de un camino sin salida, de una sociedad sin soluciones.

Los años inútiles es, no cabe duda, una novela política, con evidente voluntad de interpelar, retratándola en su conjunto, la conciencia de una sociedad extraordinariamente problemática, minada por desigualdades monstruosas, acechada por el ejército y las oligarquías, degradada por la corrupción y azotada encima por el terrorismo salvaje de Sendero Luminoso, por entonces -recuérdese- en su periodo de mayor actividad. En un momento dado, uno de los personajes realiza un largo trayecto en microbús desde el centro de Lima hasta sus más extremos suburbios, atravesando las zonas residenciales, y la secuencia de lo que va viendo constituye por sí sola toda una lección sobre Perú.

Benavides está condenado a cargar con el sambenito de la comparación con Vargas Llosa (es arequipeño, como él, y comparte incluso un remoto parecido físico). Está claro, sin embargo, que no pretende eludirlo. Los años inútiles podría ser presentado 
por un publicista sin escrúpulos como un remake semidesnatado de Conversación en La Catedral. Pero no se trata, ni mucho menos, de una novela epigonal, por mucho que su virtuosismo técnico sea deudor de la estética de la dificultad que tanto cundió por los años sesenta y setenta. No ha de extrañar, al fin y al cabo, que propósitos semejantes sean perseguidos por vías semejantes. $Y$ optar por ciertos caminos, en un plano tanto ético como formal, constituye en la actualidad, al margen de toda innovación, una suerte de radicalidad.

En Los años inútiles se perciben los efectos de una convencida ambición y de una forja prolongada. Apenas cabe cuestionar, por demasiado explícitos, la conveniencia de algunos tramos (muy en particular los del comando paramilitar). Por lo demás, la novela, admirablemente escrita, es un portentoso híbrido de literatura política y de folletín.

Pues no deja de ser descaradamente folletinesca, propia de un culebrón (jesa chica humilde accidentalmente embarazada!), la trama en que concurren las historias principales, sin que ello pueda aducirse en demérito de la veracísima crónica del fracaso y de la derrota en que sucumben sus muy bien dibujados personajes.

\subsection{Texto completo del reportaje de Francisco Igartua: ¿En qué momento se jodió el Perú?, publicado en la revista Oiga del 5 de setiembre de 1995 (Nota 19)}

En estos días efervescentes -de resurgimiento económico- que vive la República, en los que se observa, por un lado, voluntad y empeño del gobierno por realizar sus planes y cumplir las recomendaciones del FMI y del Banco Mundial, y en los que, por otro lado, se advierte un claro estilo fascista, con una desmedida arrogancia que muchas veces cae en el abuso y el atropello, bueno es mirar hacia atrás, a releer lo ya escrito. En estos días en que la economía nacional va abriendo posibilidades insospechadas de desarrollo, a la vez que va creciendo el hambre y la desocupación - 
la miseria en sus distintas tonalidades- y se comprueba cómo va el Estado fagocitándose a todas las instituciones, llevando al país a un centralismo agobiante, que la mayoría acepta por inercia o por ignorancia de lo que éste significó en nuestra historia y en la de otros pueblos; en estos días tan contradictorios y tan difíciles de analizar con sosiego, no hay mejor manera de hallar algo de luz que mirando al pasado, hurgando en las lecciones del ayer alguna explicación a los desconcertantes hechos de la palpitante actualidad.

No me ocuparé, pues, en esta edición del adiós, de destacar acongojado el comportamiento atropellador de la mayoría parlamentaria, que se niega a investigar las cuentas de los últimos años del Parlamento y decide hacer cera y pabilo con los congresistas del 80 al 90, insistiendo en tergiversar la visión histórica de la ciudadanía recordando tiempos cercanos de ingrata memoria colectiva para que el presente -al que no le faltan raterías y le sobran arrogancias napoleónicas- sólo sea comparado con el desastroso paso de Alan García por el gobierno.

Para ofrecer una visión lo más clara posible de lo que ocurre hoy ante nuestros ojos nada mejor que volver la vista atrás; para el caso, repetir -actualizándolo- el artículo que escribí hace algunos años bajo el título de "Cuándo fue que se jodió el Perú".

Esta dramática pregunta -¿Cuándo fue que se jodió el Perú?-, recogida de memoria de un texto de nuestra reciente literatura, refleja con dolorosa precisión la inquietud actual de la inteligencia peruana, que no halla en el paso de Alan García por el gobierno un episodio crucial sino apenas una desgraciada anécdota. Es una pregunta que revela la clarividente sensibilidad de quien puso por escrito esta gran interrogante nacional, que se ha hecho persistente en demanda de respuesta, de aclaración sobre nuestra existencia como país, en no pocos círculos intelectuales del Perú. Es una interrogación que se ha transformado en angustiosa necesidad de hurgar en los recovecos del pasado y del presente en busca de una explicación al 
espectáculo de descomposición que nos rodea, a pesar de los pasos positivos que en muchos campos se están dando en el gobierno del presidente Alberto Fujimori.

¿Cuándo fue que se jodió el Perú? No fue en el Incario, porque entonces estas tierras eran apenas embrión de un país no nacido. Tampoco fue en la Colonia. Eran tiempos en que la historia no existía fuera de los mares europeos -que abarcaban las aguas del mundo- y cualquier país de la periferia europea, cercano o lejano a aquella historia, estaba en el limbo, no tenía un porvenir señalado (aunque no sería ocioso apuntar de paso que los virreinatos de México y el Perú eran entonces los territorios más desarrollados de toda América).

¿Fue con la República que se jodió el Perú?

Aquí ya se trata de nuestros días y de nuestras responsabilidades. Sin embargo, los primeros decenios de vida independiente transcurren por igual, con similares rivalidades entre caudillos, en toda América Latina; sin que Lima dejara de ser en esos años la capital más importante de América del Sur. Hasta esa etapa, las posibilidades de desarrollo para la incipiente nación peruana eran iguales o mayores que las de Colombia, Chile o Argentina.

Nuestro primer gran contratiempo recién llega a mediados del siglo pasado y es obra de peruanos. Son los peruanos desterrados en Chile, con el futuro mariscal Castilla a la cabeza, los que alientan la expedición chilena que en Yungay derrota y destruye a la Confederación Perú-boliviana, creada por Santa Cruz con la visionaria intención de corregir el despechado despropósito de Bolívar y rehacer el territorio histórico del Perú.

Es imposible desde hoy, desde nuestro trágico presente, vislumbrar lo que hubiera sido la reunificación peruana, esa república que soñaron algunos espíritus 
visionarios, ese Perú que pudo ser y no fue. De todos modos, si hubiera sido un territorio más grande y más rico, con una Sierra más potente frente a la lánguida y amodorrada Lima -ciudad cuyo nombre tiene fragancia de fruta asexuada-; y quién sabe si de ahí, de un diálogo vital entre la Costa y los Andes, hubiera surgido la nación que aún no logramos forjar.

Pero la historia no se hace con lo que pudo haber sido y no fue. No podemos, por ejemplo, adivinar siquiera el Perú que hubiéramos heredado de las rebeldías de Gonzalo Pizarro o de la enloquecida correría de Lope de Aguirre por selvas, cordilleras, ríos y mares en búsqueda del reino de la libertad, que él quiso ubicar en tierras del Pirú. La historia es hija de los hechos, de lo ocurrido y constatado. No es de la imaginación ni de los deseos. Puede sí serla de los olvidos.

Es historia, por ejemplo, la glorificación en el Perú del mariscal Castilla y también es historia la canción que a diario se escucha cantar a los niños en las escuelas de Chile:

$$
\begin{aligned}
& \text { "Cantemos la gloria } \\
& \text { del triunfo marcial } \\
& \text { que el pueblo chileno } \\
& \text { obtuvo en Yungay..." }
\end{aligned}
$$

Son, en realidad, la misma historia. Pero mientras que en un lado -en Chile- se tiene memoria correcta de lo que fue un hito importante en la formación de su país como nación, en la otra parte -en el Perú- ni siquiera se recuerda que fue Castilla quien capitaneó esas huestes chilenas, destructoras de la Confederación que reunificaba al Perú que Bolívar dividió por vengarse de los desprecios de Lima.

Como vemos, no hay siquiera memoria de nuestro primer gran contratiempo, prolegómeno del segundo, del descalabro militar de 1879. 
La pérdida de la guerra postró al Perú. Lo hizo caer en el abismo de la ruina económica y moral. Y, en este caso, la humillación nos abrumó hasta tal punto que se ha hecho obsesión nacional su recuerdo. Lo que tampoco es sano ni fecundo.

Sin embargo, a pesar de esos dos tremendos desastres, no fue entonces que el Perú se jodió. Con tenacidad, con esfuerzos propios, con confianza en el destino patrio, el Perú se recuperó y, a finales del siglo pasado y comienzos del novecientos, floreció nuestra agricultura y la minería peruana respaldaba una moneda que iba "a la par con Londres". Todavía no eran los tiempos del dólar, reinaba en aquella época la libra esterlina.

Nos hallábamos, es cierto, lejos de la posición privilegiada del virreinato, pero no teníamos el porvenir perdido, el futuro nos podía sonreír en cualquier momento y había modo de contrarrestar la ventaja que nos llevaban los países hermanos bañados por el Atlántico, eje entonces del comercio y las relaciones internacionales.

Lima era una fiesta en aquellos años de la República Aristocrática -la de Piérola y Pardo- y en las provincias las injusticias ancestrales se sentían menos; ilusión del porvenir, construyó Leguía su Patria Nueva con carnavales populares, carreteras, avenidas, puertos y derroche de ilusiones financieras y juegos eléctricos. El Perú, por muy grandes que fueran sus problemas escondidos bajo las alfombras o entre los pliegues andinos, podía hacer el esfuerzo de ponerse "a la par con Londres" en cuestiones sociales, políticas y económicas. A pesar de la dictadura y el centralismo leguiísta, no había llegado la hora en que se jodió el Perú. Sí quedó sembrada con Leguía una semilla perniciosa que contribuyó con el tiempo al desastre nacional: Leguía hizo irrisión de nuestra institucionalidad. El presidente lo fue todo.

El "crac" del 29 remeció al mundo y tumbó a Leguía. Un legendario comandante, Sánchez Cerro, "el Mocho", se alzó en Arequipa y entró triunfante a Lima. Se desató 
la barbarie, pero el Perú siguió andando a pesar de la demagogia, del crimen político, de los petardos y de la anarquía que el APRA inauguró, introduciendo en el país los métodos violentos que el fascismo y el comunismo habían patentado en Europa. Y a pesar también de la violenta reacción del gobierno sanchecerrista.

Tras el asesinato de Sánchez Cerro, el general Óscar R. Benavides interviene para pacificar los ánimos e impedir que el país se paralice. Lo logra usando viejos sistemas policíacos y deja como sucesor a Manuel Prado, un personaje que no haría mover al país en ninguna dirección y no cometería imprudencias en la guerra mundial que ya estallaba. Pero, al parecer, Benavides comprendía que para el desarrollo de un país es necesaria la continuidad de acción en los gobiernos; y también parecía entender que la actividad ciudadana requiere seguridad, la que sólo puede emanar de normas legales estables. Será por esto que, en 1945, el ya mariscal Benavides propicia el Frente Democrático y la candidatura del doctor Bustamante y Rivero, quien plantea como condición irrevocable que su régimen sea de transición, de primer paso a una democracia basada en la seguridad jurídica.

La impaciencia del APRA y la torpeza militar echan por tierra este inteligente camino hacia la modernización del Perú. Vamos de tumbo en tumbo, pero vamos como esas canoas que se hunden y reaparecen en los rápidos del Colca.

En 1956 aparece rutilante la figura de Belaúnde, el arquitecto del nuevo Perú, y vuelven las ilusiones que Leguía, con habilidad de prestidigitador, supo usar para encandilar a las multitudes. Pero el vencedor de las elecciones fue Prado, el pasado que persistía. Y que persistió luego en el siguiente sexenio, a pesar de los buenos deseos y de importantes logros del presidente Belaúnde.

El Perú no resiste más y en 1968, al no decidirse Belaúnde -acorralado por el APRA y Odría- a cumplir sus promesas de cambio social, estalla la revolución militar. 
Y aquí sí es cuando se jodió el Perú. No porque fuera innecesario enterrar el pasado. Era necesario hacerlo y bien enterrado debiera estar. Era necesario abrir la sociedad peruana. Al Perú lo ahogaba una argolla medieval, una oligarquía despiadada en los negocios y cerrada, ciega, en lo social; sin aliento patrio, sin visión de futuro, ignorante de las nuevas ideas que se iban imponiendo por el mundo, huérfana de respuestas a las exigencias de la hora. Sin darse cuenta de cómo ni cuándo la clase dirigente peruana se había convertido en cadáver que caminaba, hablaba y hacía dinero explotando a otros, no por habilidad propia, sino gracias a una especie de quinto real, de monopolio concedido a ella por gracia divina.

La revolución se había hecho necesaria.

Pero entonces, ¿cómo fue que se jodió el Perú?

No fue por borrar el pasado; el Perú se jodió porque la revolución militar no supo escoger el camino para modernizar al país. Destruyó el ayer, no creó el mañana y no supo mantener el presente. No tenía ideas y se dejó desbordar por las corrientes socialistas que la revolución militar apañó y engordó; pero no por las corrientes modernas, actuales, de ese signo, sino por las más vulgares, las menos inteligentes, las afectas al resentimiento y a la destrucción. No se dejó llevar por principios que hubieran desembocado en el socialismo de Felipe Gonzales o Mitterrand, sino por planteamientos que han tenido que ser revisados en China y la Unión Soviética para evitar que el desastre las arrase.

El Perú se jodió cuando, obnubilada por los resplandores de las ideas de los cafés europeos y de la Iglesia "progresista", la revolución militar escoge equivocadamente el camino estatista, el del Ogro Filantrópico en dimensión marxista. 
La reforma agraria era necesaria. Pero fue una insensatez que afectara a los agricultores que mejor producían y que no tenían tierras ociosas. Otro disparate fue imponer por la fuerza un sistema cooperativo -que no lo era- en las grandes haciendas azucareras.

También era necesaria la reforma de la empresa y todas las otras reformas "revolucionarias". Pero hubo equivocación -y grande- cuando se creó la comunidad laboral y se introdujo la estabilidad en los puestos de trabajo; hubo torpeza cuando se estatizó no sólo la pesca sino hasta a los pescadores; y hubo delirio cuando el Estado reemplazó a los particulares y se convirtió en el gran empresario. Todas ellas, medidas que dañaron al país y no favorecieron, a pesar de sus buenas intenciones, a los trabajadores.

El Perú se jodió cuando la revolución militar optó por el estatismo en lugar de tomar el camino que el país requería: modernizarse, producir y competir en el mundo alentando la imaginación de los individuos, crear riqueza para que la justicia alcance a todos. El Perú se jodió cuando la revolución militar escogió el colectivismo y este terrible mal -productor de miseria sin quererlo y sembrador de desdichas sin saberlo- se enraizó en el país con el apoyo de todas las tendencias marxistas -que iban creciendo como espuma en medio del desconcierto general- y de todos los políticos que sólo ven votos en sus decisiones de gobierno.

Quien escribe estas líneas recuerda un encuentro callejero con Eudocio Ravines en el destierro de ambos, en México. Era el año 78 y el camino de regreso se nos abría a los deportados, aun para aquellos que teníamos proceso abierto "por haber intentado desestabilizar a la República". De esto hablábamos cuando, de pronto, tajante, el célebre removedor de inquietudes políticas, muerto trágicamente hace unos años en esa misma calle, exclamó: "No vuelvas. Ya te has abierto camino fuera y tú, en el fondo, eres un liberal. A estos militares estatistas, con absoluta seguridad, los 
reemplazará el APRA, que es mucho más estatista que los militares". Luego, al notar que no tenía acogida su consejo, con voz triste, quién sabe si adivinando que nunca volvería a la patria, que moriría atropellado en el cemento muy lejos de sus verdes valles cajamarquinos, añadió: "A mí me tienen que firmar doce generales un permiso expreso de regreso al Perú, porque once firmaron el decreto que me deportó y me quitó la nacionalidad".

Eudocio Ravines no se equivocó. A los militares colectivistas los sucedió el APRA, luego de un paréntesis en el que, como antaño, no hubo suficiente decisión de cambio.

La tragedia del Perú continuó en manos del APRA, hundiéndonos en el barro de un estatismo torpe, inmaduro, al que podríamos llamar de juguete si no hubiera producido tantos destrozos.

Dije y repito que el Perú se jodió con el gobierno militar en los años setenta; porque fue en esa época que, a la vez que se impulsó la necesaria integración nacional, se escogió como instrumento de desarrollo el colectivismo estatista, modelo que ya la experiencia mundial desaconsejaba y que ha resultado más catastrófico, castrante y negativo que cualquier otro experimento del pasado para la evolución moral, económica y jurídica del Perú. O sea que, justo en el momento en que se iniciaban los pasos para la solución al más hondo problema nacional desde el inicio de República al problema de la integración humana del Perú-, el gobierno tomó el desastroso camino del colectivismo. De este modo, la inevitable crisis económica estalló en conflicto social y el problema del indio, aunque sufriera algunos cambios, más aparentes que reales, quedó en lo mismo: siguió siendo la gran traba al desarrollo social del Perú. Fue así como se jodió el Perú. 
El hecho no ocurrió en un día equis del año 68 o del 70. Los militares que acompañaron a Velasco, igual que éste, no tenían una idea clara de lo que iban a hacer en el gobierno el día que irrumpieron en Palacio y tampoco la tuvieron en los años siguientes. Tardó un tiempo para que fueran dándose cuenta de lo que hacían, aunque nunca llegaron a ponerse de acuerdo en cuanto a las metas finales. No hay, pues, fecha para recordar y lamentar el infortunio.

Tampoco carecía de antecedentes el proceso de integración nacional que la revolución militar puso en marcha. El más reciente había sido justamente la prédica electoral del arquitecto Belaúnde y las primeras jornadas de Cooperación Popular al inicio de su régimen. Bellos instantes de diálogo fecundo, de abrazo fraterno entre peruanos de la ciudad y el campo, que desgraciadamente quedaron truncos, como cometas inconclusas que soñaron inútilmente con volar.

El Perú se jodió con la revolución militar del sesentaiocho porque, ilusamente, creímos encontrar la fuente de la felicidad en el modelo socialista. No se jodió porque en esos años se dieron pasos firmes hacia la integración peruana. No. Acelerar el paso en esa dirección era necesario para que el país fuera adquiriendo, por fin, conciencia de nación, para que los peruanos entendiéramos qué es sentido nacional. Ya que no es posible hablar de nación peruana mientras el indio, el indígena de estas tierras, no se halle incorporado, junto con los demás peruanos, a la actividad del hombre moderno; mientras no lleguemos a entender que la rabulesca eliminación de la palabra indio en el diccionario peruano no elimina -ni siquiera esconde- el problema del indio. Un problema que nos ronda desde comienzos de la República y que siempre se ha pretendido soslayar, enmascarar, olvidar. Por lo pronto, son escasos, se les podría contar con los dedos de una mano, los políticos y pensadores peruanos que han tocado sin temor el problema del indio. Entre esos pocos uno de los más lúcidos, descarnados, es José Carlos Mariátegui, quien no tiembla al hundir el dedo en la llaga cuando dice: "En el Perú, el problema de la unidad es más hondo 
porque no hay aquí que resolver una pluralidad de tradiciones locales o regionales sino una dualidad de raza, de lengua y de sentimiento, nacida de la invasión y conquista del Perú autóctono por una raza extranjera que no ha conseguido fusionarse con la raza indígena ni eliminarla ni absorverla".

He aquí el problema magistralmente expuesto. Pero ¿cuál será la solución?, ¿cuál será el destino de estas tierras? Y la respuesta es un dilema: o nos fusionamos civilizadamente, inteligentemente, corrigiendo los desatinos del siglo y medio, o Sendero eliminará salvajemente a medio Perú para levantar sobre los escombros su patria, la de los vencedores. Esta es la hora aterradora que vive el Perú.

Pero ya dije que por mirarle el rostro al problema del indio no se jodió el Perú. Al revés, por no mirarlo, o por despreciar al indio, fue que nos ocurrieron grandes desastres -como la derrota de Yungay-; pero no sigamos con el tema por ahora. Ya habrá espacio más adelante para hablar de la arrogancia, la mezquindad y la estrecha visión limeñas contra el indio Santa Cruz, contra quien planteó establecer un diálogo vital entre la Costa y la Sierra, y así llegar a la fusión, a la integración humana de los distintos Perúes.

El Perú se jodió, repito, cuando optó, en la época de la revolución militar, por el estatismo. Cuando, en lugar de insistir en la unión nacional y ajustar los instrumentos de desarrollo a esa meta superior, optó por el enfrentamiento de clases, por el odio de razas. Se jodió cuando, sin comprensión de la realidad peruana, sin captar las corrientes modernas y sin advertir los desastres que el colectivismo había ya producido en el mundo, los militares revolucionarios, instigados por un grupo de inexpertos intelectuales marxistas, escogieron como modelo el socialista. Sí, socialista, tal como está escrito; aunque en verdad se trató de un sistema ajeno al Perú y desconocedor de sus problemas, nacido de libros y de aventuras juveniles europeas, un socialismo chato, poco inteligente, muy distante de las ideas 
humanistas, samaritanas, generosas, que dieron origen a esa corriente social. Un socialismo parecidísimo al que, junto a un tenso enfrentamiento racial, quiso imponer el presidente Alan García. Como si sus principales consejeros fueran los mismos jóvenes marxistas que inspiraron los traspiés militares de los años setenta.

Porque los dioses se compadecieron de nosotros en aquellos años de la "revolución militar", el Perú no llegó a caer en el abismo cubano, aunque sí estuvimos cerca de ello. En el Perú de esos días sólo se pensó en repartir, distribuir, arrebatar. Nadie habló a las masas de producción, de rendimiento, de efectividad, de eficacia, de capacidad; y si alguien lo hacía, nadie daba un centavo por su futuro político. Menos todavía si asociaba la efectividad empresarial a la creatividad, a la imaginación del individuo, a la tenacidad, dedicación y sacrificio del propietario. Aquello tan antiguo que decía: "El ojo del amo engorda al caballo", que muy bien conocían y aplicaban nuestros abuelos.

Esas ideas desastrosas, basadas en hacer daño al que acumuló ganancias legítimas con trabajo y perseverancia, enraizaron en el Perú y se consagraron como las mejores opciones a seguir.

Todo comenzó con la Reforma Agraria.

No porque no hubiera que hacerla -como que hay que borrar y seguir borrando todo tipo de explotación e injusticia donde éstas se encuentren- sino porque esa reforma se hizo mal y sirvió para no acrecentar el rendimiento del agro sino para activar enconos y revanchas, abusos y tropelías. Los latifundios de la Sierra eran una vergüenza, porque explotaban al campesino y porque eran, además, improductivos. Hoy, la situación en la Sierra no ha variado en cuanto a productividad -los reformistas no se ocuparon de alentar y orientar al campesino- y, si bien han desaparecido los latifundistas, no faltan otros explotadores en su reemplazo. 
En la Costa era inaceptable el monopolio del algodón y el azúcar, controlado por tres o cuatro familias. Pero en lugar de dejar la industria en manos privadas y de promover auténticas cooperativas agrarias responsables de su gestión, integradas por trabajadores y técnicos, se optó por el colectivismo; y los frutos de la irresponsabilidad están a la vista. Tampoco se hizo justicia a los medianos y pequeños empresarios del campo -por lo general, ingenieros agrónomos- que habían logrado alcanzar, manteniendo buenas relaciones con sus trabajadores, grandes rendimientos en fundos de cincuenta, cien y ciento cincuenta hectáreas. A éstos jamás debió alcanzarles la reforma. Eran el motor y el futuro de nuestra agricultura.

En pocas palabras, la Reforma Agraria, desgraciadamente, significó no modernización del campo sino repartija de tierras. También hubo despojo de herramientas, maquinarias y casas- habitación. Significó la parálisis de la propiedad agrícola, porque la tierra dejó de ser un bien útil para financiar la actividad agrícola para crecer y prosperar. La tierra sólo sirvió para vegetar en ella.

Con la Reforma Agraria no aumentó la producción; al contrario, bajó y siguió bajando, porque nadie o casi nadie se atrevió a cometer el sacrilegio de ir a contrapelo de los sacrosantos mitos de esos días, como el de la Reforma Agraria, y hasta hoy hay resistencia a corregir los errores que la hacen contraproducente a los intereses del país, empobrecedora de los pobres.

(No faltará quien, al leer estas líneas, se pregunte ¿por qué oiga no apoyó en todo momento a Fujimori?... Y la interrupción vale para aclarar que esta revista se ha cansado de puntualizar que está de acuerdo con el lineamiento general de la política económica del actual régimen, pero que también, permanentemente, ha rechazado el sectarismo liberal con la misma convicción con que repudia todo fundamentalismo. Para oiga, las reglas del mercado deben tener excepciones, de acuerdo a la naturaleza de los pueblos y a las circunstancias del momento. Y también oiga está en 
desacuerdo con las exageraciones ayatolistas, como la de hacer ilimitada la propiedad de la tierra, ya que esta disposición abre las puertas al latifundismo -que siempre será nefasto- y hará posible, aunque sea en teoría, en extravagante hipótesis, que un jefe árabe despistado o borracho, o un Midas cualquiera, se haga propietario del Perú entero. ¿Por qué no fijar extensiones tan amplias como lo recomienda la técnica y dejar abierta la posibilidad de ampliar esos límites cuando el interés nacional -igual que en las expropiaciones- amerite un acuerdo de ministros para el caso; y evitar así el otro disparate que es poner impuesto a las extensiones mayores, porque eso sería castigar a la eficiencia? ¿Por qué en Europa, que algo nos aventaja en experiencia, muchas cosas no se venden sino se conceden por 99 años?... Y, para completar el paréntesis, para que quede constancia de que la abierta oposición de oiga al gobierno no es gratuita: oiga cree que un gobierno no deja de ser dictadura por tener mayoría de votos -ahí están los ejemplos de Hitler y Mussolini- y estima que todo autoritarismo es negación del civilizado estado de derecho al que aspiran todos los pueblos anhelantes de un desarrollo sostenido).

Otro de los instrumentos revolucionarios que con ilusión y sano entusiasmo puso en marcha el gobierno militar fue la Comunidad Laboral. Idea alentada, sin duda, por nobilísimos propósitos y basada en impecable teoría sobre la armonización del hombre con su trabajo. Pero una cosa son los cálculos en el papel y otra la realidad. De allí que lo que se pensó como impulso a la productividad, como sustituto del sindicato, resultó constituyéndose en un añadido a las trabas que desalientan la producción.

Lo mismo podría decirse de la estabilidad laboral. Otra ley con esas buenas intenciones que empiedran el infierno, ya que en lugar de aumentar los puestos de trabajo -que era lo que se pretendía-, éstos fueron disminuyendo. Y, peor aún, esa disposición sirvió para destruir con suma eficacia la disciplina en los centros de trabajo. 
Cuando se hicieron "irreversibles" estas disposiciones, muchas de ellas inspiradas en ideas saludables, pero todas contagiadas de resentimiento y mediocridad, a la vez que administradas por holgazanes, fue que se jodió el Perú. Fue entonces que el país comienza a desintegrarse, justo cuando la repartija se hace norma y el socialismo rampante de los cafés latinoamericanos en Europa se hace meta.

Fue un cúmulo de errores que explosionaron de pronto; errores que habíamos ido almacenando desde muy antiguo, desde aquel gran descalabro de Yungay. Porque hay que decirlo de una vez- lo que se enseña en las escuelas, lo que opina don Jorge Basadre y lo que nos escribe un lector amable sobre Santa Cruz y la Confederación Perú- boliviana es un engaño que encubre, esconde, maquilla la verdad. Una verdad que, por ser muy amarga, no es agradable reconocer. Pero que es verdad.

Nuestro primer gran contratiempo -repito- fue la destrucción de la Confederación. No porque Castilla o Gamarra hubieran sido traidores a la patria, que no lo fueron. Sólo a los peruanos nos satisface repartirnos como volante de circo el título de traidor. Sí fueron unos despistados que no vieron, ni siquiera olfatearon, lo que ocurría bajo los hechos que ellos vivían apasionadamente. Fueron políticos tan torpes que creyeron posible la anexión del Perú por Bolivia. Tremenda equivocación imperdonable en quienes se estimaban estadistas-, alentada por Chile, país que sí veía un peligro para él -para su expansión- en la Confederación. De allí que se aplicara en ser asilo grato para los refugiados peruanos. Lo que no niega que Castilla fuera más tarde un excelente y patriótico administrador y que los dos (Castilla y Gamarra) fueran valiosísimos soldados -hasta geniales estrategas si se quiere- a los que les corresponden todos los méritos y honores de la derrota que sufrieron en Yungay los confederados del indio Santa Cruz. Al jefe chileno de la expedición, general Bulnes, sólo le correspondió -para desgracia nuestra- la victoria política. Con ello cumplió los planes trazados por Diego Portales, el gran estadista chileno que halagó y amparó a los deportados peruanos que encabezaron, bajo mando chileno, 
las dos expediciones restauradoras que culminaron en Yungay. Planes y estrategia detalladamente explicados en la carta de Portales, que reproduce Jorge Basadre, y que en un párrafo dice exactamente: "Va usted, en realidad -le escribe Portales a Blanco Encalada, jefe de la primera expedición-, a conseguir con el triunfo de sus armas la segunda independencia de Chile.... La posición de Chile frente a la Confederación Perú- boliviana es insostenible. No puede ser tolerada ni por el pueblo ni por el gobierno porque ello equivaldría a su suicidio. No podemos mirar sin inquietud y mayor alarma la existencia de dos pueblos confederados y que, a la larga, por la comunidad de origen, lengua, hábitos, religión, ideas, costumbres, formarán, como es natural, un solo núcleo".

Lo que Portales veía con clarísima precisión -también así lo veía desde el campo opuesto Santa Cruz- no lo vieron los díscolos caudillos peruanos, con Castilla a la cabeza; pero, sobre todo, no lo veía la virreinal y engreída Lima, la amodorrada ciudad de la mazamorra y el arroz con leche. Tampoco lo ven nuestros historiadores y algunos de los lectores de oiga que me han escrito sobre el tema. Sí lo vio Bolívar, quien no quiso un Perú fuerte e hizo del Alto Perú una nación independiente. Y, muchas páginas atrás en la historia, así también lo vio el virrey Manuel Guirior, quien escribió en 1778 cuando se comenzó a hablar de la Audiencia de Charcas y de hacerla -como se hizo- dependencia del virreinato de Buenos Aires: "El reino del Perú, Bajo y Alto, no admite división perpetua".

Portales, con larga y aguda visión de estadista -él es el padre de la nación chilena-, advierte que es natural la unión de los dos Perúes, que el idioma -el quechua y el aimara- los unifica, que habrá con el tiempo una ligazón inseparable con Lima capital, que la Sierra y la Costa -con paridad en el diálogo- unirán capacidades y recursos. Adivina él, chileno, lo que pudo ser este país y no fue -por obra de él, en parte-, mientras que los peruanos seguimos sin captar, sin sentir el problema del indio, queriéndolo eliminar, borrando la palabra indio del diccionario. $\mathrm{O}$ 
entendiéndolo mal, soberbiamente, con desprecio, como lo entendía la frívola Lima de los años de la Confederación; la Lima que se rendía a los pies de Salaverry y Vivanco porque eran blancos, altaneros y poco sagaces; la Lima que detestó en Santa Cruz al indio. Así lo decían sus coplas:

\author{
"Que este Alejandro huanaco \\ extienda hasta el Juanambú \\ sus aspiraciones viejas. \\ ¿Por quí, humbre, el Bolivia dejas? \\ ¿Por quí boscas la Pirú?."
}

\title{
10.3. La Revolución Peruana
}

Tomado de Los Prodigiosos Años 60 (Guillermo Thorndike) (Nota 20)

Hasta las siete de la noche 3 de octubre no se sabía con certeza, quién era el nuevo jefe militar y político del Perú. No era necesario preguntar el motivo de la sublevación: la pagina once. El petróleo: ¿Pretexto o rectificación histórica? ¡Como saberlo! Las tropas involucradas en el golpe de Estado habían actuado con una determinación desconocida hasta entonces. Un coronel de rostro afilado se había llevado a Belaúnde. Cuando resplandeció el flash de los fotógrafos y el presidente quiso forcejear y liberarse, el militar se impuso, sacándolo en vilo. El Palacio amaneció bajo la protección de blindados y paracaidistas. La Guardia de Asalto formaba pelotones en plazas y calles céntricas. Grupos descontentos con el cuartelazo quisieron protestar La Colmena y la Plaza San Martín, pero la Guardia contestó a balazos. Cayeron dos muertos y varios heridos. Creció el rumor de que se encontraba al mando un general Velasco. Para el país, un desconocido. 
Velasco y los coroneles venían reuniéndose en una pequeña oficina próxima a Surquillo desde hacía varios meses. El coronel Fernández Maldonado era quien lideraba a los coroneles: Leonidas Rodríguez Figueroa, un cusqueño, Rafael Hoyos Rubio, un ranger que había sido espada de honor; Luis Gallegos Venero, de los comandos paracaidistas, también cusqueño. Solo cuatro al principio. Las instituciones se hundían borrosamente en el Perú. El problema de la tierra iba a causar una explosión social en los Andes.

Entre comuneros sin tierra y yanaconas, el descontento llegaba a millones de peruanos. Todos los coroneles habían intervenido en la lucha antiguerrillera que acabo en 1965. Ninguno ignoraba que la cordillera era una inmensa fortaleza natural. De otro lado, la Fuerza Armada necesitaba modernizarse. Las técnicas de la guerra habían cambiado vertiginosamente en los últimos anos. El Perú tenía tanques de la II Guerra Mundial. Los transportes de orugas se plantaban cada diez kilómetros por desperfectos mecánicos. Parte de las tropas aun estaba armada con fusiles Mauser de comienzos de siglo. La artillería era obsoleta. El Ejercito carecía de cohetes y de un sistema apropiado de comunicaciones Los cuarteles se caían de viejos. Los mejores oficiales abandonaban la carrera debido a necesidades económicas. Pese a los cruceros adquiridos por Prado, la escuadra nacional no podía medirse con la chilena y Chile, la pasada guerra, los territorios vacíos, despoblados entre Moquegua y Arequipa eran una obsesión para Velasco. La Fuerza Aérea aun no tenía aviones de combate supersónicos. Faltaba todo: piezas, repuestos, municiones, equipos. Llegaron otros coroneles, de uno en uno, cuidadosamente seleccionados. Ante el fracaso civil, era necesario comandar la modernización del Estado. Expropiar industrias y empresas estratégicas. El desorden sindical y las componendas de los partidos políticos serian sustituidos por una nueva organización social, que movilizara fuerzas nuevas de la población. Pero la Fuerza Armada no aceptaría un golpe de coroneles. Al principio tendrían que conceder porciones de poder a generales que habían tolerado la lenta acumulación de ese desastre. 
Velasco golpeo y no telefoneo a los jefes de las regiones militares para pedir permiso sino para comunicar que el golpe estaba consumado. El general Ernesto Montagne, que lo seguía en rango, no se atrevería a oponérsele. Generales de brigada con mando de tropas en Lima se habían sumado al movimiento antes del amanecer. Mandaba la fuerza así que demoró en ir a Palacio, quedándose cerca de las fuerzas sublevadas. Desde que rompió el día, Velasco tronó por el teléfono. No se discutía un hecho terminado: Belaunde estaba en Argentina, cuyo gobierno le había impedido reembarcarse hacia el Perú. Acabo la democracia. Ahora tenían que formar un gobierno presidido por Velasco. Una tras otra, las principales jefaturas del Ejército se le fueron entregando. Después vino la confrontación con los almirantes y los aviadores. A las cinco de la tarde empezaron a volar helicópteros sobre Lima. Ya Velasco estaba en Palacio. Llegaron los jefes navales. También los de la Fuerza Aérea. Desde las regiones militares venían los jefes a quienes Velasco encargaba nuevos cargos políticos, moviendo hacia arriba a su propia gente en los mandos militares. Al anochecer las estaciones de radio y TV entraron en cadena para mostrar al desconocido que iba a gobernar: ojillos brillantes, un bigote corto, a la antigua; una voz ronca que con las justas pudo despachar la primera proclama, de inevitable estilo castrense. Velasco no dijo que habría elecciones, ni puso límite a la intervención militar.

Aun no habían terminado de descolgar decenas de miles de retratos oficiales de Belaunde como presidente de todos los locales públicos del país, cuando sorpresivamente la radio y la TV quedaron encadenadas a Palacio de gobierno. La Junta Militar en pleno apareció de pie, en uno de los salones. Velasco invito al coronel Fernández Maldonado a que leyera un decreto ley acabado de promulgar.

Expropiaba la International Petroleum Co. La Brea y Pariñas eran del Perú y los peruanos explotarían ese petróleo. A la IPC se le expropiaba todo: la refinería de Talara, sus campamentos, maquinarias, hasta sus camiones de reparto y sus grifos. 
La IPC no era grata para el país. Se le cancelaban sus concesiones en la selva por no haberlas explorado en busca de petróleo. Después habló Velasco, con voz todavía ronca. Esa mañana, tropas de la I Región Militar habían tomado sorpresivamente el control de Talara, los campos petroleros y las instalaciones. El almirante Zimic había asumido las funciones de interventor y gobernador de la ciudad petrolera. El Perú no volvería a tolerar inmoralidades en el manejo de sus riquezas o en la negociación de contratos para explotarlas.

\subsection{El 'Limazo'.}

Reportaje de Enrique Zileri Gibson, publicado por la revista Caretas, 3 de febrero de 2000 (Nota 21)

Esta semana, en la que invasiones de tierras promovidas por elementos del propio gobierno han generado conatos de violencia masiva, coincide con el 'Limazo' de 1975 -esa orgía de vandalismo y saqueo desaforado que demostró que las grandes ciudades de países como el Perú, en las que el bienestar y la miseria contrastan dramáticamente, la química social es inestable y el estallido siempre posible si se juega irresponsablemente con las ilusiones legítimas de la gente. 

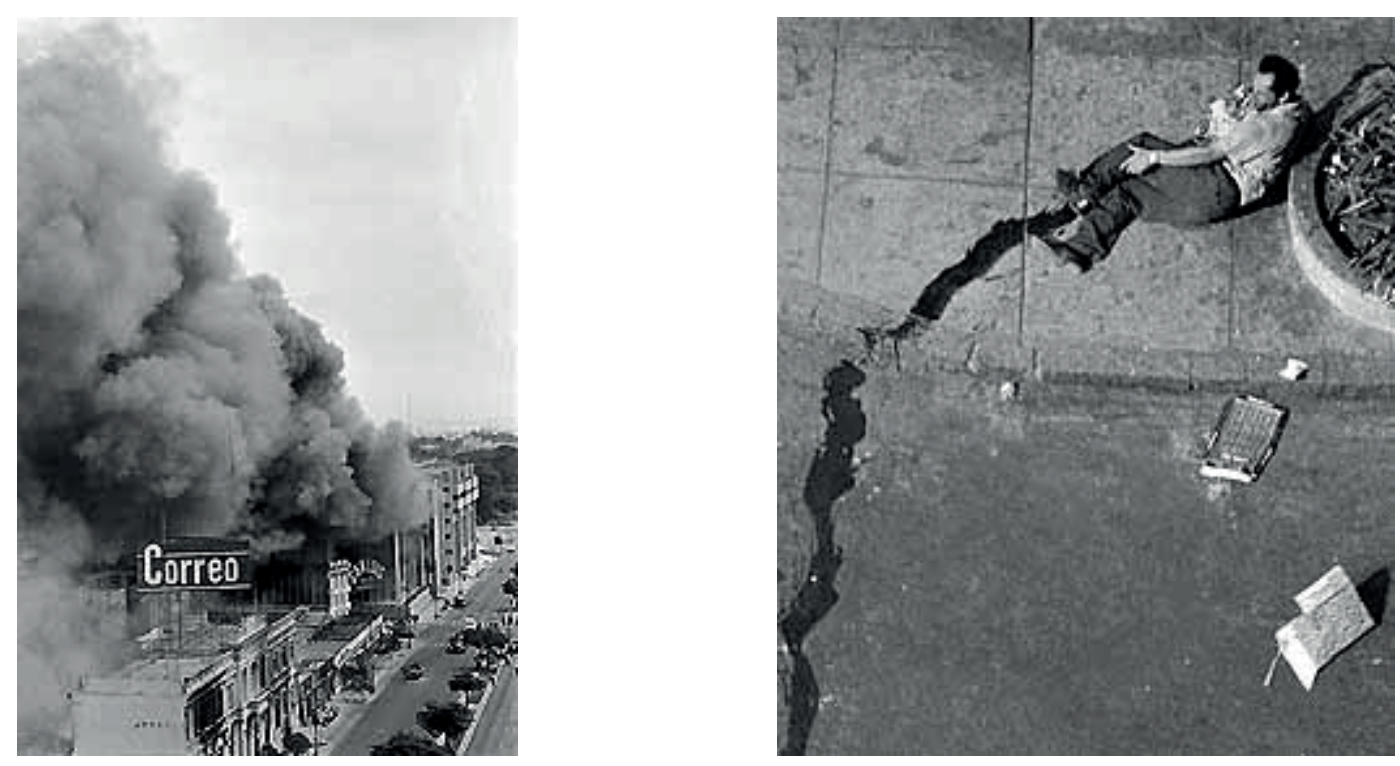

Figura 13a y Figura 13 b. Arde el Centro Cívico y amenaza al diario Correo entonces tomado por el gobierno militar. A la derecha, un saqueador pierde un pie. Texto de Caretas.

EL 5 de febrero de 1975 empezó para mí con una llamada telefónica a las 5 de la madrugada:

-¿Sabe usted que hay una revolución?- dijo una mujer anónima-. ¿Que en este momento el ejército está atacando al cuartel de Radio Patrullas en la Victoria?

Me vestí apresuradamente y dirigí mi entonces muy trajinada carcocha hacia la avenida 28 de Julio, escuchando los disparos a medida que me acercaba. De vez en cuando el tronar de una ametralladora pesada opacaba al resto.

Ya clareaba el día cuando alcancé, como parte de un gentío excitado, la esquina con Andahuaylas, divisando el muro del cuartel y un patrullero aplastado frente al portón principal.

Un tanque le había pasado por encima derribando el portón y terminando con toda resistencia.

Vi un charco de sangre al lado de una pared lateral marcada por impactos de bala y en el vecindario circulaban versiones de una masacre dentro del cuartel, y de la fuga de guardias hacia las casas aledañas. 
Después la agencia Reuters hablaría de 30 muertos en Radio Patrullas mientras el gobierno reduciría las bajas a 6 .

Con los diarios confiscados, y la radio y televisión tomadas por el gobierno militar, la mayoría de la población no estaba al tanto de que había una huelga policial. Esta se originaba en un reclamo salarial, pero lo que había desatado la confrontación era un incidente ocurrido en Palacio, en el que un general había abofeteado a un guardia por permitir que un periodista se acercara demasiado al auto presidencial.
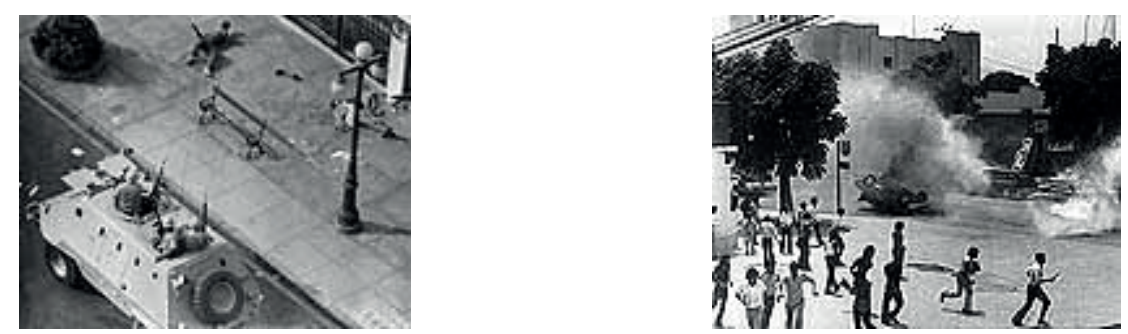

Figura 13c y Figura13d. Cacería en la avenida Emancipación. A las bajas frente a la tienda de ropa nadie las toca. Derecha, Cuando los gases lagrimógenos no sirven para nada. Texto de Caretas.

Unos 1.000 policías se habían concentrado en Radio Patrullas, el cuartel de la 41 Comandancia, en gesto de rebeldía y protesta el día anterior, y la ciudad estaba sin custodios.

Las negociaciones durante la noche fracasaron y a las 3 de la madrugada el cuartel fue rodeado por tropa y blindados, los que atacaron después de que un coronel diera un cortísimo ultimátum, de diez segundos, con un megáfono.

Un fotógrafo de CARETAS, Juan Vilca, había logrado ingresar al cuartel el día anterior, e intenté hacer averiguaciones. Fue imposible acercarse y los que buscábamos cruzar la calle éramos alejados con tiros al aire. Era el epílogo nervioso de la batalla. (Después resultó que Vilca estaba apresado en la Prefectura.) 
Un grupo de policías fue sacado con las manos en la nuca por la puerta de Bausate y Mesa, pero cuando llegué después de dar el rodeo necesario ya habían desaparecido. Aparecieron los diarios sin una palabra sobre los acontecimientos y hubo gente que en su indignación rompió ejemplares en la calle.

Entonces llegaron las primeras versiones que estaban saqueando tiendas en la Plaza Manco Cápac, y caminé hacia allá en una zona desprovista de vehículos y con mucha gente que corría.

Algo de desbarajuste capté antes de divisar con alarma las primeras columnas de humo en el centro de la ciudad y me dirigí apresuradamente hacia allá. En la Vía Expresa yacía una caseta de tránsito arrojada desde un puente.

A llegar a la Plaza San Martín y asomarme al Jirón de la Unión presencié la primera escena de saqueo masivo. Al parecer los comerciantes habían sido sorprendidos sin tiempo para bajar las cortinas de seguridad. Hombres y mujeres salían cargados de ropa, artefactos eléctricos, comestibles y todo tipo de artículos, y a veces algunos de los saqueadores que llevaban una carga excesiva eran despojados por otros. A lado mío se detuvo un motociclista con casco para observar también, y después de comentar con un extraño entusiasmo "¡qué bestias, ¿no?!", partió.

Llegué a la revista para reclutar reporteros y fotógrafos porque la edición había cerrado el día anterior, pero ya todos habían acudido y estaban trabajando. Volví a salir.
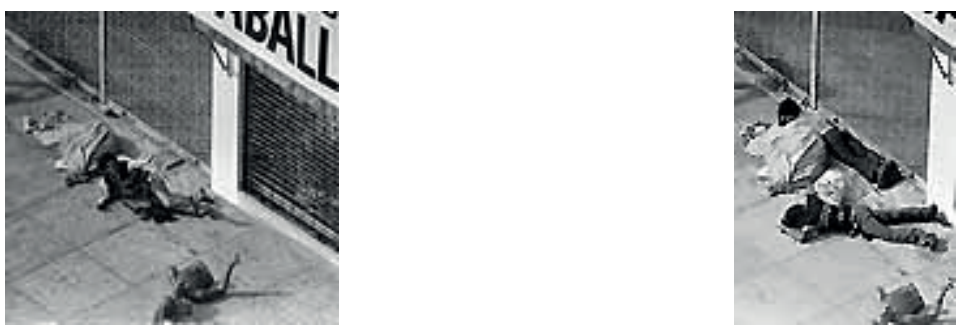

Figura 13e y Figura 13f. Entrando y saliendo en el saqueo nadie ayudó al herido, que se desangró. Texto de Caretas. 
El caos era cada vez mayor y más destructivo. Una inmensa humareda se cernía sobre la ciudad. Provenía del incendio del Centro Cívico, donde el ministro de Comercio general Luis Arias Grazziani había salido con una metralleta para intentar impedir la acción de los vándalos.

El local del Círculo Militar en la Plaza San Martín fue despanzurrado y se dice que alguien entró con una tea al Club Nacional, pero que al encontrarse con el entonces presidente de la institución Miguel Mujica Gallo, optó por salir desconcertado, 'Gaviota' le habría dicho en los términos más enérgicos: "¡Jovencito, aquí está prohibido fumar!"

Los locales de los diarios Correo, Expreso y La Crónica en poder del gobierno fueron atacados, pero la borrachera del saqueo no tenía necesariamente bandería política y del vandalismo tampoco.

El gobierno recién reaccionó a las 2 de la tarde cuando salió una columna de tanques de la División Blindada y tropa de otros cuarteles.

Una turba se había acercado a la embajada de los EE.UU. amenazadoramente cuando se oyeron algunos cañonazos de advertencia y un diplomático norteamericano acuñó una frase notable: "¡Gracias a Dios por los tanques rusos!"

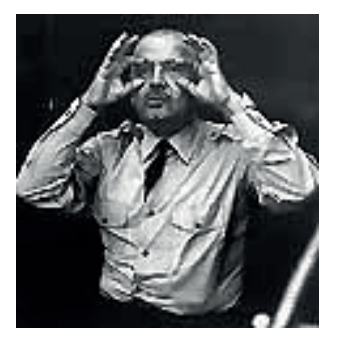

Figura 13g. El desorbitado fenómeno fue la pena de muerte del velascato. Texto de Caretas.

Entonces comenzó la verdadera balacera. En los manuales de los corresponsales de guerra se dice que más seguro resulta alejarse de las calles silenciosas en ciudades convulsionadas, porque allí están los francotiradores y los polígonos de tiro más 
peligrosos. Ese principio no regía el 5 de febrero de 1975 en Lima. Los disparos podían venir de cualquier esquina con patrullas de soldados novatos -muchos serranitos imberbes- con el corazón acelerado y el dedo en el gatillo.

Fuimos optando por observar los acontecimientos desde el techo del edificio La Nacional y algunas de las memorables fotos de estas páginas fueron captadas desde allí.

El blanco del saqueo era una tienda de ropas El en la Av. Emancipación. En la acera yacía un muerto y un herido que se desangraba, pero la turba pasaba sobre ellos al entrar y salir cargada de lo que quedaba. Periódicamente una tanqueta aparecía para espantar a la gente, disparar hacia el interior del local como quien lo fumiga de insectos, y seguir su ronda.

El muerto y el herido permanecían allí, y los saqueadores volvían a aparecer para llevarse los restos: un cenicero, un inodoro. A lo lejos vimos un helicóptero que parecía disparar hacia Chacra Colorada.

Se supo que el gobierno había decretado un toque de queda que regiría a partir de las 8 de la noche. Recordé que había dejado mi auto en La Victoria, pero con tanto saqueo consideré que nadie prestaría atención a semejante vejestorio. Así fue.

$\mathrm{Al}$ retirarnos de la azotea observamos a un desconocido junto a nosotros, un chico de unos 15 años, que llevaba puesto un terno nuevo que le quedaba enorme.

$\mathrm{Al}$ darse vuelta vimos la etiqueta y el precio. Lo sujetamos, le dimos un sermón y un buen susto, pero después lo soltamos quitándole la etiqueta de la manga. No le fuera a caer un tiro.
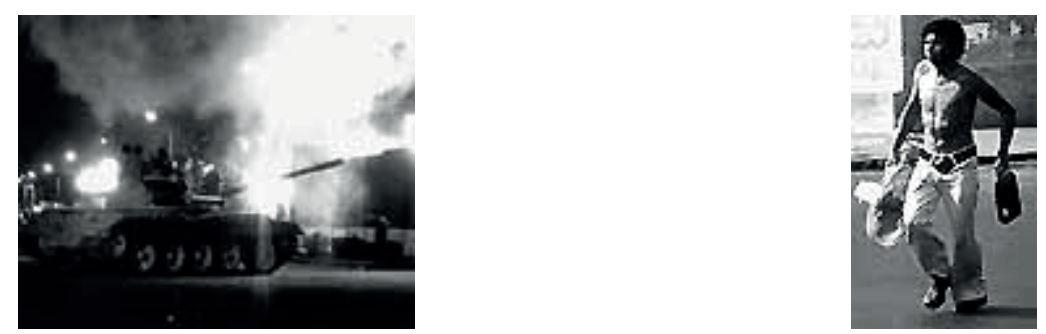
Figura 13h y Figura 13k. Advertencias de grueso calibre. Derecha, Saqueando los restos. Texto de Caretas.

\subsubsection{La Separata}

CARETAS logró imprimir un encarte de ocho páginas que apareció con la edición $\mathrm{N}^{\mathrm{o}}$ 509 un par de días después. El gobierno pronto la requisó, pero sólo parcialmente. Los canillitas escondían los ejemplares y luego los vendían a buen precio.

Ante este fenómeno el departamento de Doris Gibson, que quedaba en el mismo edificio La Nacional, fue allanado cortés pero infructuosamente. Después ella viajó a Arequipa con una maleta llena de los ejemplares prohibidos, como si fuera un cargamento de heroína.

Aventuras de la época, pero lecciones para el futuro.

Lima es una de esas ciudades que puede explotar en cualquier momento, Los gobiernos autoritarios que juegan con las expectativas del pueblo pueden estimular el caos y la violencia, y después verse obligados a tomar las medidas más drásticas para restaurar el orden.

El 'Limazo' dejó más de 100 muertos comprobados, por lo menos 1.000 heridos de bala y daños materiales enormes. El toque de queda se mantuvo durante meses. Fue la condena de muerte del velascato. 